\title{
A Role for the MS Analysis of Nucleic Acids in the Post-Genomics Age
}

\author{
Daniele Fabris \\ Department of Chemistry and Biochemistry, University of Maryland Baltimore County, Baltimore, \\ Maryland, USA
}

\begin{abstract}
The advances of mass spectrometry in the analysis of nucleic acids have tracked very closely the exciting developments of instrumentation and ancillary technologies, which have taken place over the years. However, their diffusion in the broader life sciences community has been and will be linked to the ever evolving focus of biomedical research and its changing demands. Before the completion of the Human Genome Project, great emphasis was placed on sequencing technologies that could help accomplish this project of exceptional scale. After the publication of the human genome, the emphasis switched toward techniques dedicated to the exploration of sequences not coding for actual protein products, which amount to the vast majority of transcribed elements. The broad range of capabilities offered by mass spectrometry is rapidly advancing this platform to the forefront of the technologies employed for the structure-function investigation of these noncoding elements. Increasing focus on the characterization of functional assemblies and their specific interactions has prompted a re-evaluation of what has been traditionally construed as nucleic acid analysis by mass spectrometry. Inspired by the accelerating expansion of the broader field of nucleic acid research, new applications to fundamental biological studies and drug discovery will help redefine the evolving role of MS-analysis of nucleic acids in the post-genomics age. (J Am Soc Mass Spectrom 2010, 21, 1-13) (c 2010 Published by Elsevier Inc. on behalf of American Society for Mass Spectrometry
\end{abstract}

$\mathrm{T}$ The development of technologies for the analysis of nucleic acids by mass spectrometry (MS) has followed step-by-step the evolution of the field, with the introduction of electrospray ionization (ESI) $[1,2]$ and matrix assisted laser desorption ionization (MALDI) [3, 4] representing watershed events that clearly delimit two different eras. Before the advent of these ionization techniques, the realm of application consisted mainly of the analysis of fundamental units and components of limited size, such as nucleosides (Figure 1) [5, 6], nucleotides [7, 8], and small oligonucleotides [9-11], which often required derivatization of their highly polar functional groups to increase volatility and to improve analytical performance. Overcoming inherent technical challenges, this era established MS as an irreplaceable tool for the characterization of rare nucleotides produced by normal post-transcriptional processes [12-14] and aberrant chemical damage [1517]. Efforts aimed at elucidating the building blocks of these biopolymers culminated in the creation of a comprehensive database of RNA modifications (available at http://library.med.utah.edu/RNAmods/) [1820], which today constitutes an invaluable resource for the broader life sciences community. Proceeding forward in this type of pursuit, MS-technologies continue

Address reprint requests to Dr. D. Fabris, Department of Chemistry and Biochemistry, University of Maryland Baltimore County, 1000 Hilltop Circle, Baltimore, MD 21228, USA. E-mail: fabris@umbc.edu to support the identification of DNA adducts produced by alkylating agents, carcinogens, and antitumor drugs [21-24].

\section{Making Headways in Biomedical Research}

The introduction of ESI and MALDI made progressively larger nucleic acids accessible to MS analysis (Figure 2) [25-28], which ushered in a period of rapid expansion into different areas of biomedical research. The challenges posed by the larger analytes were answered by the development of new strategies and experimental methods (reviewed in references [29-33]), which sought to take full advantage of favorable characteristics exhibited by these ionization techniques, such as their intrinsic low-energy and ability to handle highly polar species. In the early 1990s, the rapid advance of these technologies was largely fueled by the demand for analytical platforms capable of affording reliable and cost-effective DNA sequencing, which was associated with the inception of the Human Genome Project [34, 35]. Different approaches were devised to obtain unambiguous sequence information through the gas-phase dissociation of selected precursor ions in MS/MS experiments [36-38], or the molecular mass determination of ladder products obtained in solution by terminating chain elongation [39-41], or inducing
(C) 2010 Published by Elsevier Inc. on behalf of American Society for Mass Spectrometry. 1044-0305/10/\$32.00

doi:10.1016/j.jasms.2009.09.006
Published online September 17, 2009 Received July 4, 2009 Revised September 4, 2009 Accepted September 4, 2009 
(a)

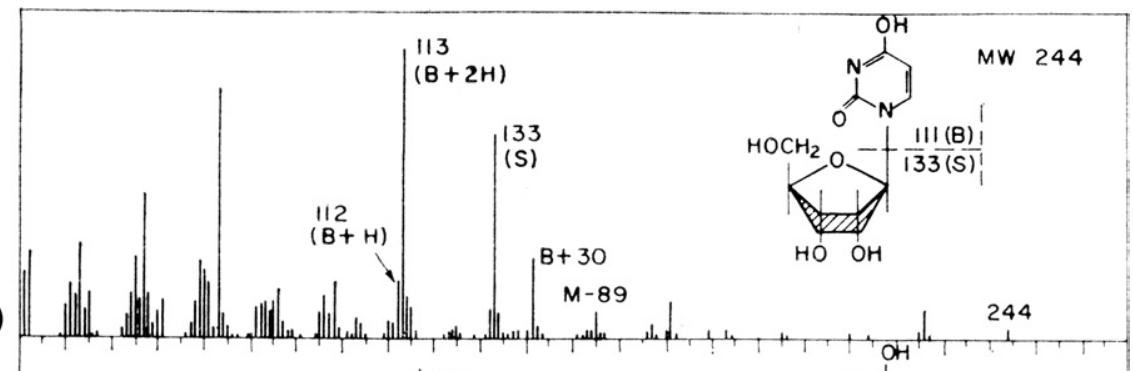

(b)

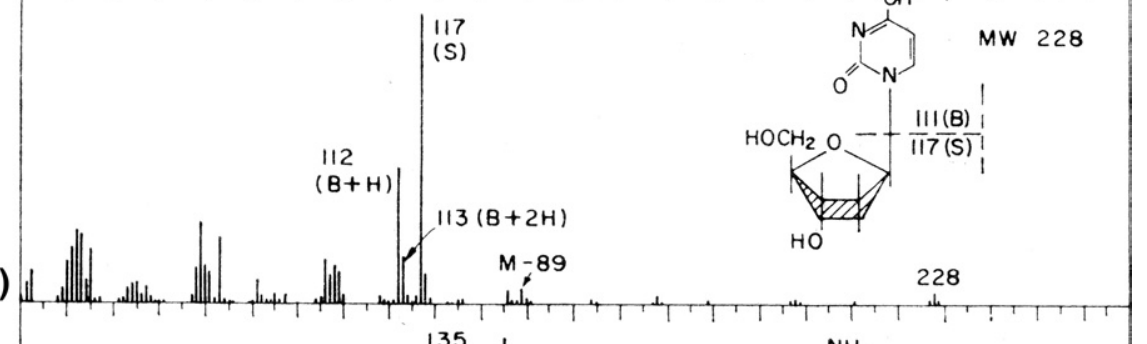

(c)

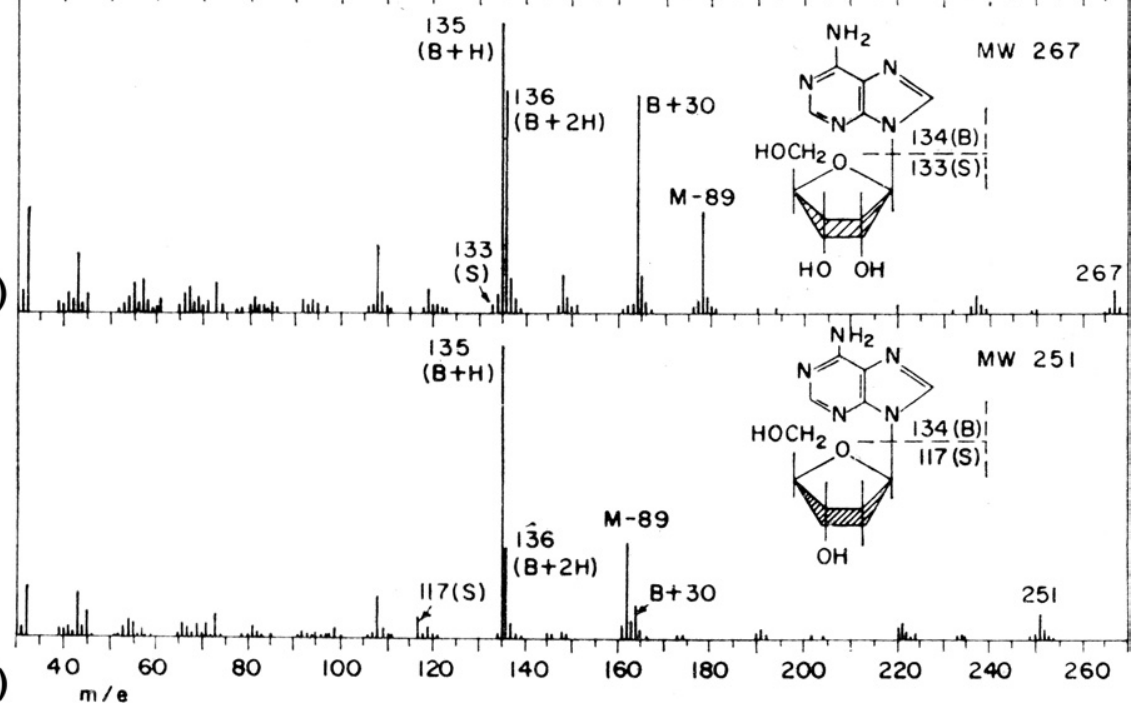

(d)

Figure 1. Electron ionization-time of flight (EI-TOF) mass spectra of (a) uridine, (b) deoxyuridine, (c) adenosine, and (d) deoxyadenosine. Samples were sublimed from the surface of a hot filament directly into the ionizing electron beam. Species of greater polar character, such as for example the corresponding mononucleotides, required derivatization to enable vaporization. Reproduced from reference [5], with permission.

partial degradation of target sequences (Figure 3) [4244] (reviewed in references [45-47]). The expectations were that high-throughput MS sequencing would play a significant role in this project of unprecedented scale by handling a fair share of the $\sim 3$ billion base pair genome. Additionally, the new approaches were expected to make MS the platform of choice for applications in medical diagnostics and for securing the information necessary to implement personalized medicine. By the mid-1990s, however, it was clear that such approaches could not overtake the concomitant advances made by sequencing strategies based on electrophoresis [48-50], which were capable of handling longer DNA segments, afforded greater multiplexing capabilities, and were significantly less expensive [51]. In 1997, a well-publicized editorial conceded that competitive MS technologies would not be ready to contribute before the then-looming completion of the Human
Genome Project, but predicted that a bright future was still in store for genotyping and diagnostic applications [52]. This prediction was realized by the introduction of technologies for the rapid characterization of single nucleotide polymorphisms [53-55] and for the detection/identification of infectious pathogens [56-58]. At the time of this editorial, however, the broader MS community had been already shifting its attention toward the burgeoning field of MS-based proteomics [59-61].

\section{Confronting New Challenges in the Post-Genomics Era}

The completion of the Human Genome Project has brought to light surprising facts and posed new challenges [62-64]. Its results have led to conservative 


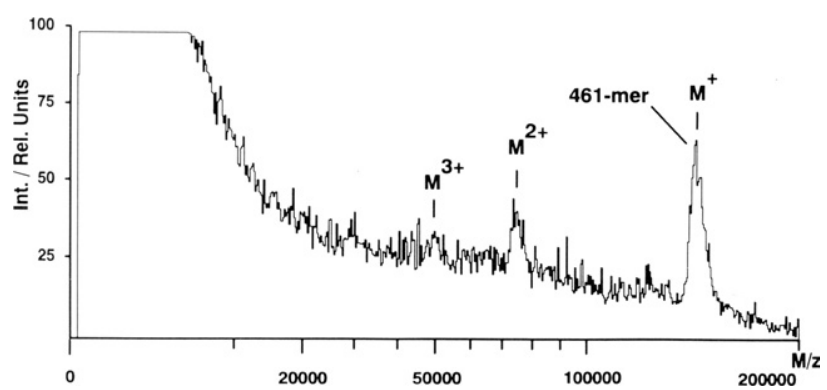

Figure 2. MALDI-MS spectrum of a 461-nucleotide RNA transcript. The analysis was performed in positive ion mode after removing the $5^{\prime}$ phosphate by treatment with calf intestine phosphatase. The ability to handle larger nucleic acid analytes paved the way for increasing applications in the life sciences. Reproduced from reference [25], with permission.

estimates that less than $1.5 \%$ of the entire genome may be coding for actual proteins, in spite of the observation that at least $70 \%$ of its sequence is transcribed into RNA $[65,66]$. Once upon a time dismissed as "selfish" or "junk DNA" [67, 68], the intragenic (i.e., intronic) and intergenic sequences representing the vast majority of the transcribed pool are now undergoing extensive re-evaluation. Indeed, the last decade has witnessed resurgent interest in the elucidation of the functions of noncoding elements (ncRNA) [69-71]. Although new classes of functional RNA are being discovered on a regular basis, their total amount still does not account for the entire transcribed pool [72]. These discoveries have keenly pointed out that sequence information alone is not sufficient to reveal the function of all classes of ncRNAs and to explain their mechanism of action. This conclusion is substantiated, for example, by the investigation of the activity of microRNAs (miRNAs) and riboswitches, which are receiving a great deal of attention for their participation in complex gene-regulation networks. In the case of miRNAs [73, 74], their $\sim 22-$ nucleotide sequence enables specific recognition of mRNA targets in the cell [75], but the factors driving the proper selection of cognate proteins to produce active RNA-protein complexes (miRNPs) or determining whether a certain miRNP may induce down- or upregulation of protein production remain to be elucidated [76]. In the case of riboswitches [77, 78], expression of downstream gene(s) is modulated by conformational changes induced by the interaction of a specific cellular component (e.g., metabolite, metal ion, etc.) with the 3D structure of the sensing domain, which cannot be predicted or explained according to the simple rules of base-pairing recognition $[79,80]$. These examples clearly highlight the need for technologies capable of providing not only the higher-order structure of non-coding elements, but also unambiguous information about the identity of cognate ligands, the nature of their interactions, and the effects of binding on structure and dynamics. Beyond its well-developed sequencing capabilities, MS possesses unique strengths that could advance this analytical platform to the forefront of the technologies employed for the discovery and structure-function elucidation of noncoding nucleic acids.

The potential of MS-technologies for large scale analysis of cellular RNAs has been demonstrated by the implementation of fingerprinting strategies based on endonuclease digestion of total tRNA extracts, followed by MALDI-MS detection of signature products (Figure 4) $[81,82]$. Analogous to approaches employed in quantitative proteomics, ${ }^{18} \mathrm{O}$ end-labeling by nuclease digestion can be employed to evaluate RNA production and observe possible variations in the amount of posttranscriptionally modified nucleotides [83]. The development of these types of approaches will be expected to benefit the growing field of experimental RNomics by complementing current technologies based on microarray techniques and cDNA-based "deep sequencing," which can provide comprehensive views of entire cellular transcriptomes [84, 85]. In fact, the dependence of established technologies on amplification/sequencing and electrophoretic analysis makes them ill-suited for the detection of possible post-transcriptional modifications, which is likely the cause of our insufficient understanding of the extent and biological significance of ncRNA modifications. MS-based strategies for the investigation of post-transcriptional modifications on a full transcriptome scale, analogous to those available for the identification of post-translational modifications of proteins on a full proteome scale, could provide missing information on the biological activities of noncoding elements and take their study in unexpected directions.

The most significant contributions to experimental RNomics, however, could arguably arise from the availability of complementary ionization/desorption techniques, which have pushed MS closer to becoming a

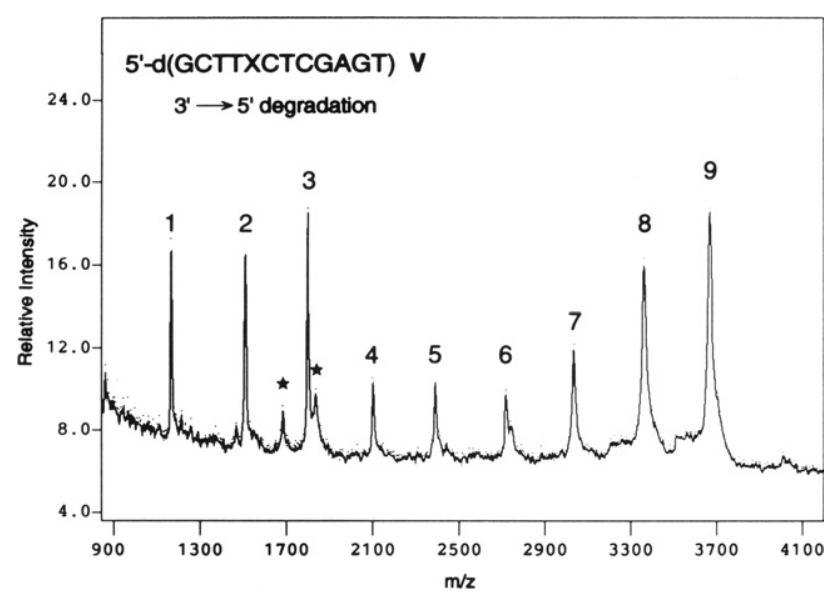

Figure 3. MALDI-MS spectrum of ladder products obtained by digesting oligonucleotide $\mathrm{V}, 5^{\prime}-\mathrm{d}(\mathrm{GCTTXCTCGAGT)}$, with the 3'-exonuclease snake venom phosphodiesterase; 2'-O-methyladenosine is indicated by X. The mass difference between contiguous peaks corresponds to that of the cleaved nucleotide. Monitoring the progress of digestion reactions as a function of time provided an effective way for tackling larger substrates by obtaining partial overlapping snapshots of their entire sequences. Reproduced from reference [42], with permission. 
(a)
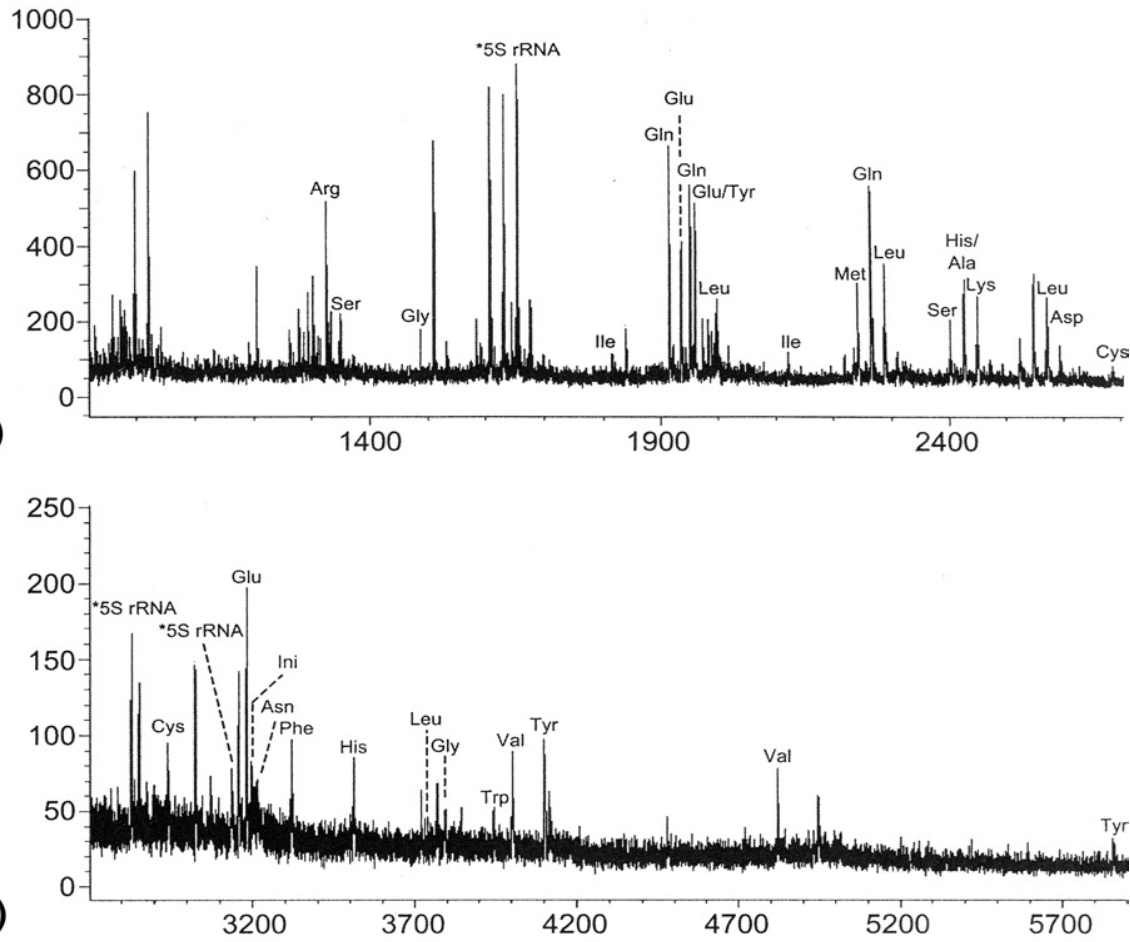

(b)

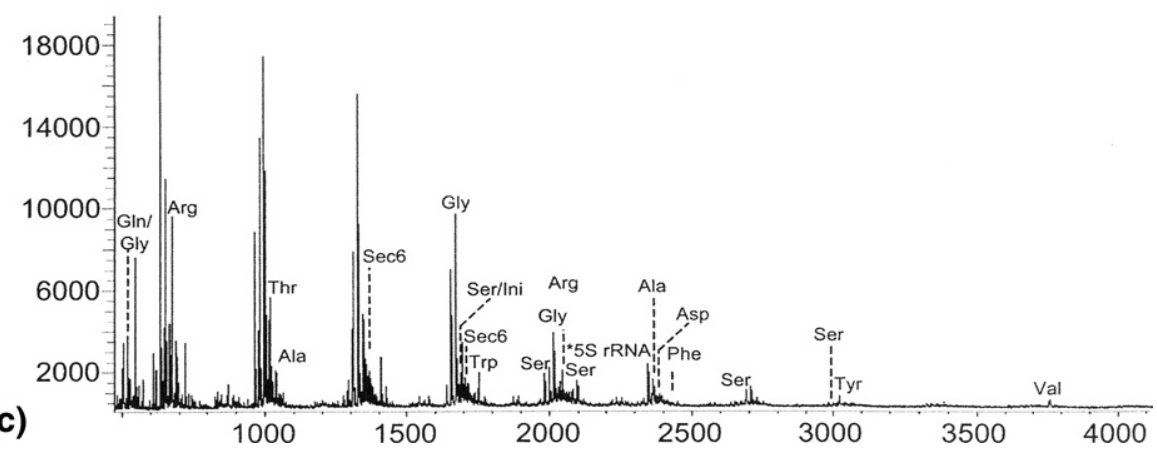

Figure 4. MALDI-MS spectra obtained from total E. coli tRNA after digestion with either RNase T1 (a) and (b), or RNase A (c). These experiments demonstrated that the detection of unique digestion products, or signatures, can provide the identification of individual isoacceptors present in the tRNA pool of a certain cell. Reproduced from reference [81], with permission.

universal analytical platform applicable to samples of virtually any type and origin. This uncanny flexibility could be harnessed to achieve the characterization of any ligand co-purified with a target nucleic acid of interest, which could represent the constitutive elements of a putative functional assembly. To this effect, affinity chromatography and related "pull-down" strategies have been routinely employed to recognize cognate proteins interacting with specific RNA [86] and DNA [87] sequences (reviewed in references [88-90]). Similar strategies could be readily adapted to identify any type of biomolecule or small molecule ligand that may be capable of binding a certain construct with sufficient affinity, taking advantage of a growing number of metabolome databases for correct assignments [91-94]. This type of scheme could represent an excellent complement to microarray technologies involving the immobilization of specific RNA sequences covering the de- sired portion of the transcribed pool. Reversing the terms of this experimental design, the ligand of interest could be immobilized to enable the isolation of any nucleic acid structure with specific binding activity, thus leading to the identification of cognate sequences that may be involved with the selected ligand in biologically active assemblies. High-throughput schemes could be implemented to perform systematic screening of sequences capable of binding series of metabolites involved in the same or parallel pathways, or representative compounds from selected classes of xenobiotics. The potential in this direction is still largely untapped.

\section{Elucidating Structure-Function Relationships}

Mass spectrometry offers additional capabilities that make it an invaluable platform for the study of the structure-function relationships of these types of nu- 
cleic acids. The activity of most noncoding elements known to date is associated with their ability to establish specific interactions with other cellular components. Therefore, their elucidation places a premium on the possibility of observing intact functional assemblies and probing their salient structural features. The advent of soft ionization techniques and the advances of analyzers design have made this possibility a reality. Indeed, relatively short duplexes formed by complementary deoxyoligonucleotides were among the first noncovalent complexes detected by ESI without unwelcome dissociation [95-97]. Although this desirable outcome can be obtained also by MALDI with a judicious selection of matrix, additives, and other experimental conditions [98-101], ESI remains the ionization technique of choice for the detection of nucleic acid noncovalent assemblies (reviewed in references [102-105]).

Direct ESI-MS analysis of nucleic acid complexes with other nucleic acids [106-110], proteins [111-116], and small molecule ligands [117-120] can reveal their exact composition and stoichiometry from the observed molecular mass, dispensing with the typical curvefitting of bulk data required by spectroscopic and calorimetric methods. Unlike these techniques, MS is capable of resolving any free/bound species at equilibrium in solution, even when such species possess very similar spectroscopic characteristics. With proper experimental design and data treatment, their respective signal intensities can be employed to obtain relative
[121, 122] and absolute [123-128] dissociation constants $\left(\mathrm{K}_{\mathrm{d}}{ }^{\prime} \mathrm{s}\right)$ in solution, matching those afforded by established methods [129]. In this direction, competitive binding experiments in which multiple ligands are mixed simultaneously with the substrate of interest have proven very effective in providing relative scales of binding affinities based on the aspect ratio and distribution of the detected complexes [130-133]. Reversing the terms of the competition scheme, a ligand of interest can be also added to multiple substrates simultaneously, for example, to directly compare the effects of subtle variations in substrate structure on binding mode (Figure 5) [134]. In more rigorous fashion, quantitative determinations of $\mathrm{K}_{\mathrm{d}}$ can be accomplished by following titration schemes in which the amount of ligand is increased stepwise and the abundances of free/bound species in solution are determined after each addition [125-128]. Possible dissociative effects induced by adding a certain ligand to a preformed complex can be also assessed to obtain quantitative determinations of inhibition constants $\left(\mathrm{K}_{\mathrm{i}}{ }^{\prime} \mathrm{s}\right)$ or ligand concentrations inducing $50 \%$ dissociation of the initial complex $\left(\mathrm{IC}_{50}{ }^{\prime} \mathrm{s}\right)$ [135]. It is expected that these approaches will become increasingly popular as desirable features, such as limited sample consumption and exemption from radio- or fluorescent-labeling, will become better known within the broader life sciences community.

In addition to information attainable by taking

(a)

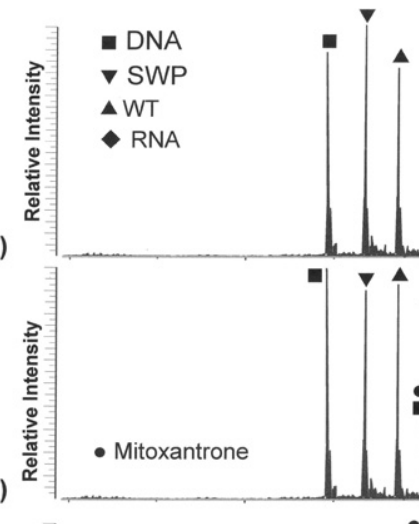

No Ligand

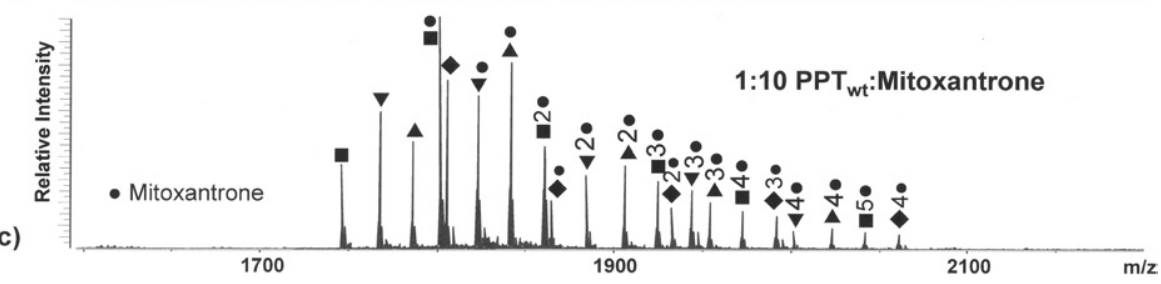

Figure 5. (a) ESI-MS spectrum of an equimolar mixture of substrates consisting of the HIV-1 polypurine tract DNA:RNA hybrid duplex $\left(\mathrm{PPT}_{\mathrm{WT}}\right)$, its DNA:DNA and RNA:RNA versions $\left(\mathrm{PPT}_{\mathrm{DNA}}\right.$ and $\mathrm{PPT}_{\mathrm{RNA}}$, respectively), and a duplex in which the wild type DNA and RNA sequences are swapped $\left(\mathrm{PPT}_{\mathrm{SWP}}\right)$. (b) ESI-MS spectrum obtained after addition of 1 equivalent of the anticancer drug mitoxantrone. (c) ESI-MS spectrum after addition of 10 equivalents of ligand. With the exception of $\mathrm{PPT}_{\mathrm{DNA}}$, which was found capable of binding up to five mitoxantrone units, all the other substrates supported the binding of up to four units under the selected experimental conditions. The results provided the following relative scale of binding affinities: $\mathrm{PPT}_{\mathrm{DNA}}>\mathrm{PPT}_{\mathrm{WT}} \approx \mathrm{PPT}_{\mathrm{RNA}} \approx \mathrm{PPT}_{\mathrm{SWP}}$. Reproduced from reference [134], with permission. 
"snapshots" of species at equilibrium in solution, mass spectrometry can provide further insights into the nature of the interactions involved in functional nucleic acid assemblies by studying them in the gas-phase. The dissociation of these species has been activated directly in the ESI source [136-138], or after ion selection in MS/MS experiments [139-141], to assess their stability and to glean valuable details about determinant structural features [142-145]. For example, the dissociation of duplex structures in the absence/presence of ligands has been investigated to demonstrate the preservation of Watson-Crick pairing and stacking interactions in the gas phase and to elucidate the effects of selected binders on the stability of these interactions [142-146]. Conversely, analogous experiments have been completed to study the effects of ligand structure on binding mode $[110,136,147]$. A great deal of effort has been dedicated over the years to understand the fundamentals, to conciliate gas-phase observations with solution behaviors, and to enable predictions of experimental outcome from structural information and vice versa.

Finally, mass spectrometry can be also employed to elucidate higher-order structures of nucleic acids and their functional assemblies by following a variety of solution and gas-phase approaches. Chemical footprinting and bifunctional crosslinking have been combined with MS analysis to reveal the position of base-pairing interactions, which define elements of secondary structure of nucleic acids, or to identify long-range contacts between discrete domains, which outline tertiary structures and determine the global fold of the larger species [148-151]. The spatial constraints obtained by these approaches constitute valid input for performing molecular modeling by established computational methods, thus enabling the creation of all-atom 3D models based on actual experimental data (Figure 6) [152, 153]. Crosslinking strategies can also help identify the contacts between nucleic acids and cognate proteins [154-157] and reveal the organization of multisubunit functional complexes [158-160]. The possible application of hydrogen/deuterium exchange (HDX) to characterize the contact interfaces between assembled units has been hampered by the fast exchange rate exhibited in solution by the nucleic acid components [161, 162]. However, this approach has been successfully employed to highlight the protein surfaces in contact with them and to study the dynamics associated with the specific interactions [163-165]. The implementation of HDX in the gas phase has been demonstrated for nucleotides [166, 167], unstructured oligonucleotides [168], and relatively small structured constructs $[169,170]$, but its application to the larger assemblies has yet to be reported.

Gas-phase approaches have been developed to map ligand sites and to gain precious insights into the architecture of large multi-subunit assemblies with nucleic acid components. Under suitable activation conditions, the binding of selected ligands to RNA substrates can prevent underlying nucleotides from undergoing the typical backbone fragmentation that produces the characteristic ion series employed in MS/MS sequenc-

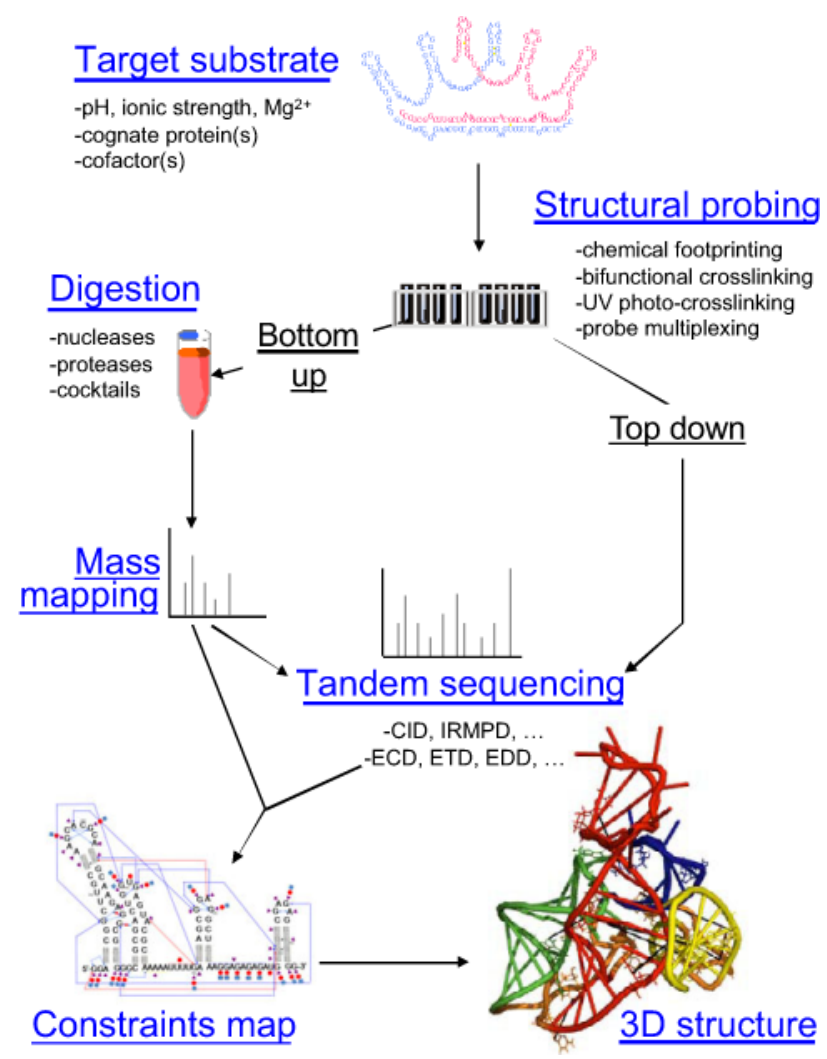

Figure 6. General workflow for 3D-structure determination of nucleic acids based on structural probing and MS analysis (MS3D). The substrate is probed under ideal conditions preserving its native fold. Characterization of the ensuing covalent adducts can be performed under denaturing conditions, following either bottom-up or top-down approaches. The positions of probed nucleotides provide spatial constraints that are summarized on 2D maps, from which a complete, all-atom 3D structure can be readily generated through established molecular modeling protocols.

ing. This observation has promoted strategies for achieving the characterization of specific binding sites onto target nucleic acid structures, which are revealed by recognizable gaps in the detected ion series [134, 171, 172]. Conversely, the same protection effects can be employed to screen libraries of small molecule ligands for their ability to bind to desired structural motifs, which is evaluated from their power to induce sitedirected inhibition of nucleic acid fragmentation [123, 173]. In the absence of covalent fragmentation, the order by which bound subunits dissociate as discrete products may reveal their spatial situation within the complex of interest. Indeed, submitting intact ribosomes and their constitutive subunits to collisional activation induced the progressive release of protein units according to their affinity for each other and for the RNA components, but also according to their placement relative to the surface of the initial precursor ion $[138,174]$. In similar fashion, the dissociation of RNA-RNA pairing interactions was employed to interrogate the conformational state of assemblies folding into alternative isomeric forms [175]. In this example, the pattern afforded by collisional activa- 
tion clearly differentiated dimeric complexes capable of assuming either a loop-loop kissing or an extendedduplex conformation in the presence of their cognate viral protein (Figure 7), which provided new insights into the mechanism of structure remodeling mediated by the chaperone protein. The conformational study of progressively larger assemblies will be expected to take full advantage of recent exciting developments in ion mobility mass spectrometry, which has been already shown to be capable of affording direct information about nucleic acid structures in the gas phase $[169,176]$.

\section{The Road Ahead}

The unquestionable benefits offered by MS technologies for nucleic acid analysis come with intrinsic challenges posed by the very nature of these biomolecules. Some of these challenges are general and apply to any analytical platform, such as those concerning the integrity of RNA samples, which require utilizing RNase-free solvents, plastic ware, and tools to stave off rapid degradation. Others are specific to the MS platform, such as those originating from the presence of phosphate groups in the biopolymer structure, which affect the selection of sample preparation and mode of analysis. Indeed, the negative charges afforded by these functional groups confer nucleic acids a strong tendency to form un- wanted cation adducts that can deteriorate the attainable resolution and signal to noise ratio. Over the years, alternative strategies have been devised to replace metal cations with the more volatile ammonium [42, 177], which employ ion-exchange [178], reversed-phase high-performance liquid chromatography [179], metal chelation [180, 181], ethanol precipitation [177], ultrafiltration, and microdialysis [182-184]. Although separationbased desalting is very effective for these types of biomolecules, it may also result in the unwanted dissociation of their noncovalent assemblies, either through excessive reduction of the solution ionic strength, or through direct perturbation of binding equilibria. In these cases, a viable alternative consist of performing ion-ion reactions with specific metal chelators, which can be accomplished in the gas phase after the desorption process is complete and equilibrium considerations are no longer a concern [185].

The presence of phosphate groups makes negative ion mode the preferred mode of operation for the MS analysis of nucleic acids. However, the sensitivity limits achieved in this polarity appear to be consistently worse than those afforded in the positive ion mode by the same instrumentation/technique. While this practical observation is well-known in the MS community, its causes are still not understood. Addressing this discrepancy will be critical for the direct analysis of cellular

(a)

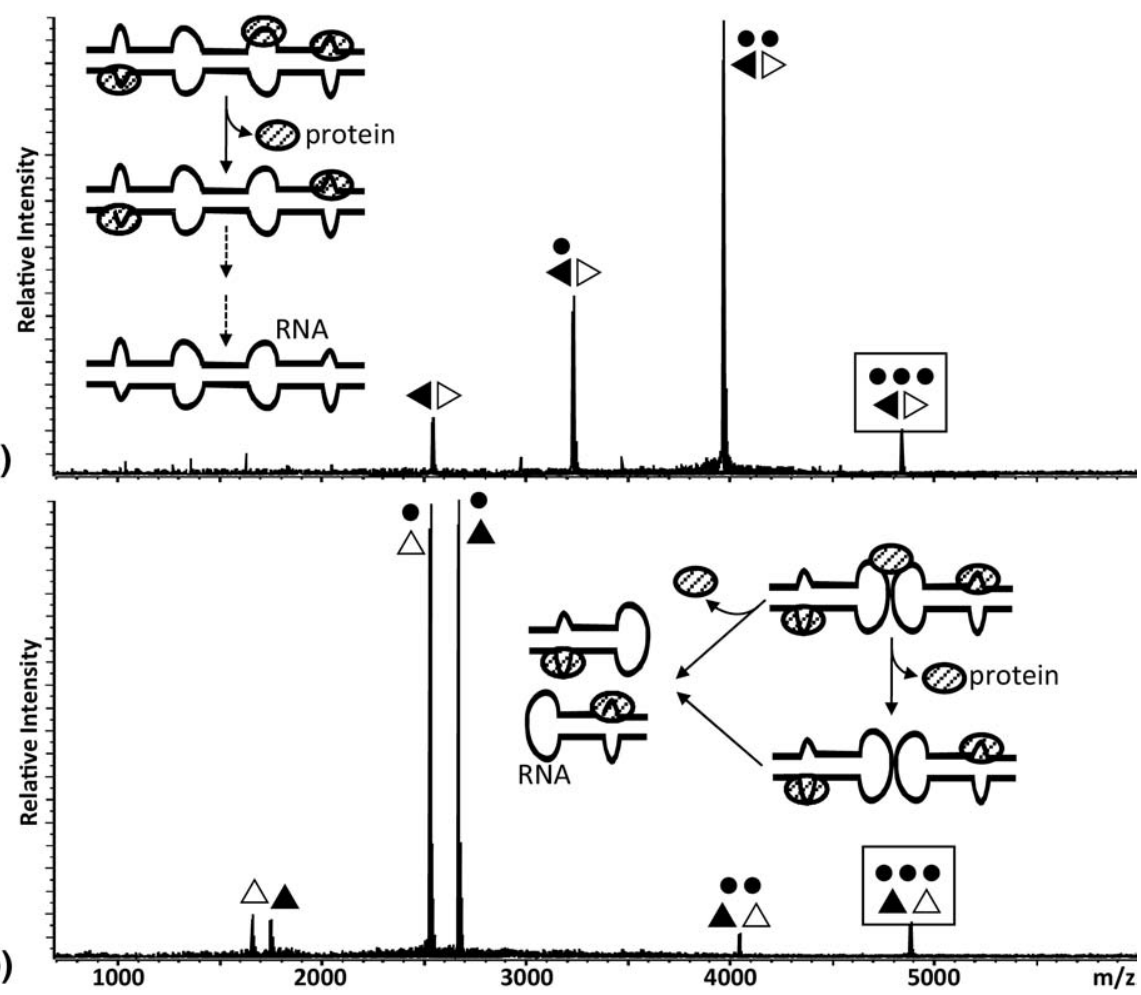

Figure 7. Collision-induced dissociation (CID) mass spectra obtained from a 3:2 protein-RNA assembly folded in either extended-duplex or loop-loop kissing conformation, (a) and (b), respectively. Proteins are represented by circles, RNA strands by triangles. Squares mark the remaining precursor ions. The extended-duplex complex displayed sequential loss of protein units, whereas the loop-loop conformer underwent dissociation of interstrand pairings to provide 1:1 protein-RNA products. Adapted with permission from reference [175]. 
analytes without additional amplification procedures. In the same direction, gas-phase activation techniques, such as electron capture dissociation (ECD) [186] and electron-transfer dissociation (ETD) [187], have been extensively investigated for sequence analysis of proteins and peptides in cationic form. However, the exploration of equivalent methods for the activation of anionic precursors and their application to nucleic acids are still at a very early stage [188].

Clearly, the multifaceted capabilities summarized here provide a strong rationale for a broader application of mass spectrometry to the structure-function investigation of nucleic acids. If the ever increasing demands of the post-genomics age extend beyond the need for mere sequence information, a new definition of what can be considered as MS analysis of nucleic acids should be formulated, which should include also the analysis of their complexes with other biomolecules, physiologic ligands, and xenobiotics. In many cases, the physical-chemical characteristics and structural stability of these functional assemblies are still largely determined by the nucleic acid components, even when such components amount to only a small fraction of the entire complex under investigation. In the case of protein-nucleic acid conjugates, for example, a high density of negatively-charged phosphates may affect the overall charge balance and may become a critical factor in the selection of polarity and mode of operation. A higher propensity to form cation adducts may command the adoption of protocols for sample preparation, which are more commonly associated with analytes of purely nucleic acid nature. For these reasons, while the protein moiety could still be perceived as the critical component according to strict functional considerations, analytical considerations could make the nucleic acid moiety the focus of attention, due to the more stringent requirements imposed on the MS analysis. Often, what we call "substrate" or "ligand" becomes a question of perspective.

Now, if the range of information accessible by MSbased technologies is so astonishingly wide, then why isn't their application more popular in the broader life sciences community? Part of the answer may be found in the intrinsic technical challenges posed by these types of experiments, which may require know-how that has yet to spread beyond a few dedicated laboratories. However, the progressive refinement of these technologies, the streamlining of experimental strategies, the complementary capabilities and advantages over established methodologies, as well as the nearly capillary diffusion of MS instrumentation, should contribute to a considerable expansion in coming years. Part of the answer may be found in the actual size of the public engaged in this field of research, which is still a small portion of the broader life sciences community and includes only a handful of commercial enterprises with a continued stake in nucleic acids. After all, the proportion of nucleic acid-targeted drugs in the market is miniscule in comparison with that of protein-targeted therapeutics. However, with less than $1.5 \%$ of the human genome coding for proteins, the potential for discovering viable targets among the remaining transcribed elements is too large to be ignored. MS-technologies will be expected to play a very significant role in the exploration of this extensive druggable space, supporting traditional tasks in drug discovery, as well as new strategies for the identification of possible targets and therapeutic candidates. When antisense and gene silencing technologies will overcome the last remaining hurdles that hamper their widespread introduction in human therapy, MS will be uniquely placed to accomplish the operations required by manufacturing and regulatory monitoring. Combined with new applications to fundamental biological studies, the activities spurred by the changing demands of a rapidly developing field will help redefine the evolving role of MS analysis of nucleic acids in the post-genomics age.

\section{Acknowledgments}

This research was funded by the National Institutes of Health (R01-GM643208 and R21-NS063871) and the National Science Foundation (CHE-0439067).

\section{References}

1. Yamashita, M.; Fenn, J. B. Electrospray Ion Source. Another Variation on the Free-Jet Theme. J. Phys. Chem. 1984, 88, 4671-4675.

2. Aleksandrov, M. L.; Gall, L. N.; Krasnov, V. N.; Nikolaev, V. I. Pavlenko, V. A.; Shkurov, V. A. Extraction of Ions from Solutions Under Atmospheric Pressure: A Method of Mass Spectrometric Analysis of Bioorganic Compounds. Doklady Akademii Nauk 1984, 277, 379-383.

3. Tanaka, K.; Ido, H.; Yoshida, Y.; Yoshida, T. Detection of High Mass Molecules by Laser Desorption Time-of-Flight Mass Spectrometry. Proceedings of the Second Japan-China Joint Symposium on Mass Spectrometry; Osaka: Bando Press, Osaka, 1987

4. Karas, M.; Bachmann, D.; Bahr, U.; Hillenkamp, F. Matrix-Assisted Ultraviolet Laser Desorption of Nonvolatile Compounds. Int. J. Mass Spectrom. Ion Processes 1987, 78, 53-68.

5. Biemann, K.; McCloskey, J. A. Application of Mass Spectrometry to Structure Problems. VI. Nucleosides. J. Am. Chem. Soc. 1962, 84(10), 2005-2007.

6. Hattox, S. E.; McCloskey, J. A. Structure-Retention Relationships in the Gas Chromatography of Nucleosides. Anal. Chem. 1974, 46(11), 13781383.

7. McCloskey, J. A.; Lawson, A. M.; Tsuboyama, K.; Krueger, P. M.; Stillwell, R. N. Mass Spectrometry of Nucleic Acid Components. Trimethylsilyl Derivatives of Nucleotides, Nucleosides, and Bases. J. Am. Chem. Soc. 1068, 90(15), 4182-4184.

8. Lawson, A. M.; Stillwell, R.N.; Tacker, M. M.; Tsuboyama, K.; McCloskey, J. A. Mass Spectrometry of Nucleic Acid Components. Trimethylsilyl Derivatives of Nucleotides. J. Am. Chem. Soc. 1971, 93(4), 1014-1023.

9. McNeal, C. J.; Ogilvie, K. K.; Theriault, N. Y.; Nemer, M. J. A New Method for Sequencing Fully Protected Oligonucleotides Using ${ }^{252} \mathrm{Cf}$ Plasma Desorption Mass Spectrometry. Negative Ions of Dinucleoside Monophosphates. J. Am. Chem. Soc. 1982, 104, 972-975.

10. Grotjahn, L.; Frank, R.; Blocker, H. Ultrafast Sequencing of Oligodeoxyribonucleotides by FAB-Mass Spectrometry. Nucleic Acids Res. 1982, 10(15),4671-4678.

11. Cerny, R. L.; Tomer, K. B.; Gross, M. L.; Grotjahn, L. Fast Atom Bombardment Combined with Tandem Mass Spectrometry for Determining Structures of Small Oligonucleotides. Anal. Biochem. 1987, 165(1), 175-182.

12. McCloskey, J. A.; Nishimura, S. Modified Nucleosides in Transfer RNA. Acc. Chem. Res. 1977, 10(11), 403-410.

13. Pang, H.; Smith, D. L.; Crain, P. F.; Yamaizumi, K.; Nishimura, S. McCloskey, J. A. Identification of Nucleosides in Hydrolysates of Transfer RNA by High-Resolution Mass Spectrometry. Eur. J. Biochem. $1982,127(3), 459-471$.

14. McCloskey, J. A. Structural Characterization of Natural Nucleosides by Mass Spectrometry. Acc. Chem. Res. 1991, 24(3), 81-88.

15. Lijinsky, W.; Loo, J.; Ross, A. E. Mechanism of Alkylation of Nucleic Acids by Nitrosodimethylamine. Nature 1968, 218(5147), 1174-1175. 
16. Cadet, J.; Weinfeld, M. Detecting DNA Damage. Anal, Chem. 1993, 65(15), 675A-682A

17. Farmer, P. B.; Sweetman, G. M. A. Mass Spectrometric Detection of Carcinogen Adducts. J. Mass Spectrom. 1995, 30, 1369-1379.

18. Limbach, P. A.; Crain, P. F.; McCloskey, J. A. Summary: The Modified Nucleosides of RNA. Nucleic Acids Res. 1994, 22(12), 2183-2196.

19. Crain, P. F.; McCloskey, J. A. The RNA Modification Database. Nucleic Acids Res. 1007, 25(1), 126-127.

20. McCloskey, J. A.; Crain, P. F. The RNA Modification Database-1998. Nucleic Acids Res. 1998, 26(1), 196-197.

21. Apruzzese, W. A.; Vouros, P. Analysis of DNA Adducts by Capillary Methods Coupled to Mass Spectrometry: A Perspective. J. Chromatogr. A 1998, 794(1/2), 97-108.

22. Tretyakova, N.; Matter, B.; Ogdie, A.; Wishnok, J. S.; Tannenbaum, S.R. Locating Nucleobase Lesions Within DNA Sequences by MALDI-TOF Mass Spectral Analysis of Exonuclease Ladders. Chem. Res. Toxicol. 2001, 14(8), 1058-1070.

23. Wang, Y.; Zhang, Q.; Wang, Y. Tandem Mass Spectrometry for the Determination of the Sites of DNA Interstrand Cross-Link. J. Am. Soc. Mass Spectrom. 2004,1 5(11), 1565-1571.

24. Singh, R.; Farmer, P. B. Liquid Chromatography-Electrospray IonizationMass Spectrometry: The Future of DNA Adduct Detection. Carcinogenesis 2006, 27(2), 178-196.

25. Kirpekar, F.; Nordhoff, E.; Kristiansen, K.; Roepstorff, P.; Lezius, A.; Hahner, S.; Karas, M.; Hillenkamp, F. Matrix Assisted Laser Desorption/Ionization Mass Spectrometry of Enzymatically Synthesized RNA up to $150 \mathrm{kDa}$. Nucleic Acids Res. 1994, 22(19), 3866-3870.

26. Tang, K.; Taranenko, N. I.; Allman, S. L. L. Y.; Chang, L. Y.; Chen, C. H. Detection of 500-Nucleotide DNA by Laser Desorption Mass Spectrometry. Rapid Commun. Mass Spectrom. 1994, 8, 727-730.

27. Chen, R.; Cheng, X.; Mitchell, D. W.; Hofstadler, S. A.; Wu, Q.; Rockwood, A. L.; Sherman, M. G.; Smith, R. D. Trapping, Detection, and Mass Determination of Coliphage T4 DNA Ions of $10^{8}$ Da by Electrospray Ionization Fourier Transform Ion Cyclotron Resonance Mass Spectrometry. Anal. Chem. 1995, 67, 1159-1168.

28. Muddiman, D. C.; Null, A. P.; Hannis, JC. Precise Mass Measurement of a Double-Stranded 500 Base-Pair (309 kDa) Polymerase Chain Reaction Product by Negative Ion Electrospray Ionization Fourier Transform Ion Cyclotron Resonance Mass Spectrometry. Rapid Commun. Mass Spectrom. 1999, 13(12), 1201-1204.

29. Limbach, P. A.; Crain, P. F.; McCloskey, J. A. Characterization of Oligonucleotides and Nucleic Acids by Mass Spectrometry. Curr. Opin. Biotechnol. 1995, 6(1), 96-102.

30. Nordhoff, E.; Kirpekar, F.; Roepstorff, P. Mass Spectrometry of Nucleic Acids. Mass Spectrom. Rev. 1996, 15, 67-138.

31. Banoub, J. H.; Newton, R. P.; Esmans, E.; Ewing, D. F.; Mackenzie, G. Recent Developments in Mass Spectrometry for the Characterization of Nucleosides, Nucleotides, Oligonucleotides, and Nucleic Acids. Chem. Rev. 2005, 105(5), 1869-1915.

32. Frahm, J. L.; Muddiman, D. C. Nucleic Acid Analysis by Fourier Transform Ion Cyclotron Resonance Mass Spectrometry at the Beginning of the Twenty-First Century. Curr. Pharm. Des. 2005, 11(20), 2593-2613.

33. Hofstadler, S. A.; Sannes-Lowery, K. A.; Hannis, J. C. Analysis of nucleic acids by FTICR MS. Mass Spectrom. Rev. 2005, 24, 265-285.

34. National Research Council, Mapping and Sequencing the Human Genome; National Academy Press: Washington, DC, 1988.

35. Watson, J. D.; Jordan, E. The Human Genome Program at the National Institutes of Health. Genomics 1989, 5(3), 654-656.

36. McLuckey, S. A.; Habibi-Goudarzi, S. Decompositions of Multiply Charged Oligonucleotide Anions. J. Am. Chem. Soc. 1993, 115, 1208512095.

37. Little, D. P.; Chorush, R. A.; Spier, J. P.; Senko, M. W.; Kelleher, N. L.; McLafferty, FW. Rapid Sequencing of Oligonucleotides by HighResolution Mass Spectrometry. J. Am. Chem. Soc. 1994, 116, 4893-4897.

38. Ni, J.; Pomerantz, C.; Rozenski, J.; Zhang, Y.; McCloskey, J. A. Interpretation of Oligonucleotide Mass Spectra for Determination of Sequence Using Electrospray Ionization and Tandem Mass Spectrometry. Anal. Chem. 1996, 68(13), 1989-1999.

39. Fitzgerald, M. C.; Zhu, L.; Smith, L. M. The Analysis of Mock DNA-Sequencing Reactions Using Matrix-Assisted Laser Desorption Ionization Mass Spectrometry. Rapid Commun. Mass Spectrom. 1993, 7, 895-897.

40. Shaler, T. A.; Tan, Y.; Wickham, J. N.; Wu, K. J.; Becker, C. H. Analysis of Enzymatic DNA Sequencing Reactions by Matrix-Assisted Laser Desorption/Ionization Time-of-Flight Mass Spectrometry. Rapid Commun. Mass Spectrom. 1995, 9, 1172-1176.

41. Koster, H.; Tang, K.; Fu, D. J.; Braun, A.; van den Boom, D.; Smith, C. L.; Cotter, R. J.; Cantor, C. R. A Strategy for Rapid and Efficient DNA Sequencing by Mass Spectrometry. Nat. Biotechnol. 1996, 14(9), 1123-1128.

42. Pieles, U.; Zurcher, W.; Schar, M.; Moser, H. E. Matrix-Assisted Laser Desorption Ionization Time-of-Flight Mass Spectrometry: A Powerful Tool for the Mass and Sequence Analysis of Natural and Modified Oligonucleotides. Nucleic Acids Res. 1993, 21(14), 3191-3196.

43. Limbach, P. A.; McCloskey, J. A.; Crain, P. F. Enzymatic Sequencing of Oligonucleotides with Electrospray Mass Spectrometry. Nucleic Acids Res. Symp. Ser. 1994, 31, 127-128.
44. Bentzley, C. M.; Johnston, M. V.; Larsen, B. S.; Gutteridge, S. Oligonucleotide Sequence and Composition Determined by Matrix-Assisted Laser Desorption/Ionization. Anal. Chem. 1996, 68(13), 2141-2146.

45. Smith, L. M. The Future of DNA Sequencing. Science 1993, 262(5133), 530-532.

46. Murray, K.K. DNA Sequencing by Mass Spectrometry. J. Mass Spectrom. 1996, 31(11), 1203-1215.

47. Limbach, P. A. Indirect Mass Spectrometric Methods for Characterizing and Sequencing Oligonucleotides. Mass Spectrom. Rev. 1996, 15 297-336.

48. Swerdlow, H.; Gesteland, R. Capillary Gel Electrophoresis for Rapid, High Resolution DNA Sequencing. Nucleic Acids Res. 1990, 18(6), 1415-1419.

49. Luckey, J. A.; Drossman, H.; Kostichka, A. J.; Mead, D. A.; D'Cunha, J.; Norris, T. B.; Smith, L. M. High Speed DNA Sequencing by Capillary Electrophoresis. Nucleic Acids Res. 1990, 18(15), 4417-4421.

50. Hunkapiller, T.; Kaiser, R. J.; Koop, B. F.; Hood, L. Large-Scale and Automated DNA Sequence Determination. Science 1991, 254(5028), 59-67.

51. Venter, J. C.; Smith, H. O.; Hood, L. A New Strategy for Genome Sequencing. Nature 1996, 381(6581), 364-366.

52. Henry, C. Can MS Really Compete in the DNA World? Anal. Chem. $1997,69,243 \mathrm{~A}-246 \mathrm{~A}$.

53. Little, D. P.; Braun, A.; Darnhofer-Demar, B.; Koster, H. Identification of Apolipoprotein E Polymorphisms Using Temperature Cycled Primer Oligo Base Extension and Mass Spectrometry. Eur. J. Clin. Chem. Clin. Biochem. 1997, 35(7), 545-548.

54. Haff, L. A.; Smirnov, I. P. Single-Nucleotide Polymorphism Identification Assays Using a Thermostable DNA Polymerase and Delayed Extraction MALDI-TOF Mass Spectrometry. Genome Res. 1997, 7(4) 378-388.

55. Tost, J.; Gut, I. G. Genotyping Single Nucleotide Polymorphisms by Mass Spectrometry. Mass Spectrom Rev. 2002; 21(6), 388-418.

56. Hofstadler, S. A.; Sampath, R.; Blyn, L. B.; Eshoo, M. W.; Hall, T. A.; Jiang, Y.; Drader, J. J.; Hannis, J. C.; Sannes-Lowery, K. A.; Cummins, L. B.; Libby, B.; Walcott, D. J.; Schink, A.; Massire, C.; Ranken, R.; Gutierrez, J.; Manalili, S.; Ivy, C.; Melton, R. E.; Levene, H. M. Barrett-Wilt, G.; Li, F.; Zapp, V.; White, N.; Samant, V.; McNeil, J. A.; Knize, D. J.; Robbins, D. W.; Rudnick, K.; Desai, A.; Moradi, E.; Ecker, D. TIGER: The Universal Biosensor. Int. J. Mass Spectrom. 2005, 242 $23-41$

57. Ecker, D. J.; Sampath, R.; Blyn, L. B.; Eshoo, M. W.; Ivy, C.; Ecker, J. A.; Libby, B.; Samant, V.; Sannes-Lowery, K. A.; Melton, R. E.; Russell, K.; Freed, N.; Barrozo, C.; Wu, J.; Rudnick, K.; Desai, A.; Moradi, E.; Knize, D. J.; Robbins, D. W.; Hannis, J. C.; Harrell, P. M.; Massire, C.; Hall, T. A.; Jiang, Y.; Ranken, R.; Drader, J. J.; White, N.; McNeil, J. A.; Crooke, S. T.; Hofstadler, S. A. Rapid Identification and Strain-Typing of Respiratory Pathogens for Epidemic Surveillance. Proc. Natl. Acad. Sci. U.S.A. 2005, 102(22), 8012-8017.

58. Sampath, R.; Hall, T. A.; Massire, C.; Li, F.; Blyn, L. B.; Eshoo, M. W. Hofstadler, S. A.; Ecker, D. J. Rapid Identification of Emerging Infectious Agents Using PCR and Electrospray Ionization Mass Spectrometry. Ann. N.Y. Acad. Sci. 2007, 1102, 109-120.

59. Henzel, W. J.; Billeci, T. M.; Stults, J. T.; Wong, S. C.; Grimley, C.; Watanabe, C. Identifying Proteins from Two-Dimensional Gels by Molecular Mass Searching of Peptide Fragments in Protein Sequence Databases. Proc. Natl. Acad. Sci. U.S.A. 1993, 90, 5011-5015.

60. Shevchenko, A.; Jensen, O. N.; Podtelejnikov, A. V.; Sagliocco, F.; Wilm, M.; Vorm, O.; Mortensen, P.; Shevchenko, A.; Boucherie, H.; Mann, M. Linking Genome and Proteome by Mass Spectrometry: Large-Scale Identification of Yeast Proteins from Two-Dimensional Gels. Proc. Natl. Acad. Sci. U.S.A. 1996, 93(25), 14440-14445.

61. Aebersold, R.; Mann, M. Mass-Spectrometry-Based Proteomics. Nature 2003, 422, 198-207.

62. Lander, E. S.; Linton, L. M.; Birren, B.; Nusbaum, C.; Zody, M. C. Baldwin, J.; Devon, K.; Dewar, K.; Doyle, M.; FitzHugh, W.; Funke, R.; Gage, D.; Harris, K.; Heaford, A.; Howland, J.; Kann, L.; Lehoczky, J. LeVine, R.; McEwan, P.; McKernan, K.; Meldrim, J.; Mesirov, J. P.; Miranda, C.; Morris, W.; Naylor, J.; Raymond, C.; Rosetti, M.; Santos, R.; Sheridan, A.; Sougnez, C.; Stange-Thomann, N.; Stojanovic, N.; Subramanian, A.; Wyman, D.; Rogers, J.; Sulston, J.; Ainscough, R.; Beck, S.; Bentley, D.; Burton, J.; Clee, C.; Carter, N.; Coulson, A.; Deadman, R.; Deloukas, P.; Dunham, A.; Dunham, I.; Durbin, R.; French, L.; Grafham, D.; Gregory, S.; Hubbard, T.; Humphray, S.; Hunt, A.; Jones, M.; Lloyd, C.; McMurray, A.; Matthews, L.; Mercer, S.; Milne, S.; Mullikin, J. C.; Mungall, A.; Plumb, R.; Ross, M.; Shownkeen, R.; Sims, S.; Waterston, R. H.; Wilson, R. K.; Hillier, L. W.; McPherson, J. D.; Marra, M. A.; Mardis, E. R.; Fulton, L. A.; Chinwalla, A. T.; Pepin, K. H.; Gish, W. R.; Chissoe, S. L.; Wendl, M. C.; Delehaunty, K. D.; Miner, T. L.; Delehaunty, A.; Kramer, J. B.; Cook, L. L.; Fulton, R. S.; Johnson, D. L.; Minx, P. J.; Clifton, S. W.; Hawkins, T.; Branscomb, E.; Predki, P.; Richardson, P.; Wenning, S.; Slezak, T.; Doggett, N.; Cheng, J. F.; Olsen, A.; Lucas, S.; Elkin, C.; Uberbacher, E.; Frazier, M.; Gibbs, R. A.; Muzny, D. M.; Scherer, S. E.; Bouck, J. B.; Sodergren, E. J.; Worley, K. C.; Rives, C. M.; Gorrell, J. H.; Metzker, M. L.; Naylor, S. L.; Kucherlapati, R. S.; Nelson, D. L.; Weinstock, G. M.; Sakaki, Y.; Fujiyama, A.; Hattori, M.; Yada, T.; Toyoda, A.; Itoh, T.; Kawagoe, C.; Watanabe, H.; Totoki, Y.; Taylor, T.; Weissenbach, J.; Heilig, R.; Saurin, W.; Artiguenave, F.; Brottier, P.; Bruls, T.; Pelletier, E.; Robert, C.; Wincker, P.; Smith, D. R.; Doucette-Stamm, L.; Rubenfield, M.; Weinstock, K.; Lee, H. M.; Dubois, J.; Rosenthal, A.; Platzer, M.; Nyakatura, 
G.; Taudien, S.; Rump, A.; Yang, H.; Yu, J.; Wang, J.; Huang, G.; Gu, J.; Hood, L.; Rowen, L.; Madan, A.; Oin, S.; Davis, R. W.; Federspiel, N. A. Abola, A. P. Proctor, M. J. Myers, R. M. Schmutz, J* Dickson, M.; Grimwood, J.; Cox, D. R.; Olson, M. V.; Kaul, R.; Raymond, C.; Shimizu, N.; Kawasaki, K.; Minoshima, S.; Evans, G. A.; Athanasiou, M.; Schultz, R.; Roe, B. A.; Chen, F.; Pan, H.; Ramser, J.; Lehrach, H.; Reinhardt, R.McCombie, W. R.; de la Bastide, M.; Dedhia, N.; Blocker, H.; Hornischer, K.; Nordsiek, G.; Agarwala, R.; Aravind, L.; Bailey, J. A.; Bateman, A.; Batzoglou, S.; Birney, E.; Bork, P.; Brown, D. G.; Burge, C. B.; Cerutti, L.; Chen, H. C.; Church, D.; Clamp, M.; Copley, R. R.; Doerks, T.; Eddy, S. R.; Eichler, E. E.; Furey, T. S.; Galagan, J.; Gilbert, J. G.; Harmon, C.; Hayashizaki, Y.; Haussler, D.; Hermjakob, H.; Hokamp, K.; Jang, W.; Johnson, L. S.; Jones, T. A.; Kasif, S.; Kaspryzk, A.; Kennedy, S.; Kent, W. J.; Kitts, P.; Koonin, E. V.; Korf, I.; Kulp, D.; Lancet, D.; Lowe, T. M.; McLysaght, A.; Mikkelsen, T.; Moran, J. V.; Mulder, N.; Pollara, V. J.; Ponting, C. P.; Schuler, G.; Schultz, J.; Slater, G.; Smit, A. F.; Stupka, E.; Szustakowski, J.; Thierry-Mieg, D.; Thierry-Mieg, J.; Wagner, L.; Wallis, J.; Wheeler, R.; Williams, A.; Wolf, Y. I.; Wolfe, K. H.; Yang, S. P.; Yeh, R. F.; Collins, F.; Guyer, M. S.; Peterson, J.; Felsenfeld, A.; Wetterstrand, K. A.; Patrinos, A.; Morgan, M. J.; de Jong, P.; Catanese, J. J.; Osoegawa, K.; Shizuya, H.; Choi, S.; Chen, Y. J. Initial Sequencing and Analysis of the Human Genome. Nature 2001, 409(6822), 860-921.

63. Venter, J. C.; Adams, M. D.; Myers, E. W.; Li, P. W.; Mural, R. J.; Sutton, G. G.; Smith, H. O.; Yandell, M.; Evans, C. A.; Holt, R. A.; Gocayne, J. D.; Amanatides, P.; Ballew, R. M.; Huson, D. H.; Wortman, J. R.; Zhang, Q.; Kodira, C. D.; Zheng, X. H.; Chen, L.; Skupski, M.; Subramanian, G.; Thomas, P. D.; Zhang, J.; Gabor Miklos, G. L.; Nelson, C.; Broder, S.; Clark, A. G.; Nadeau, J.; McKusick, V. A.; Zinder, N.; Levine, A. J.; Roberts, R. J.; Simon, M.; Slayman, C.; Hunkapiller, M.; Bolanos, R.; Delcher, A.; Dew, I.; Fasulo, D.; Flanigan, M.; Florea, L.; Halpern, A.; Hannenhalli, S.; Kravitz, S.; Levy, S.; Mobarry, C.; Reinert, K.; Remington, K.; Abu-Threideh, J.; Beasley, E.; Biddick, K.; Bonazzi, V.; Brandon, R.; Cargill, M.; Chandramouliswaran, I.; Charlab, R.; Chaturvedi, K.; Deng, Z.; Di Francesco, V.; Dunn, P.; Eilbeck, K.; Evangelista, C.; Gabrielian, A. E.; Gan, W.; Ge, W. Gong, F.; Gu, Z.; Guan, P.; Heiman, T. J.; Higgins, M. E.; Ji, R. R.; Ke, Z.; Ketchum, K. A.; Lai, Z.; Lei, Y.; Li, Z.; Li, J.; Liang, Y.; Lin, X.; Lu, F.; Merkulov, G. V.; Milshina, N.; Moore, H. M.; Naik, A. K.; Narayan, V. A.; Neelam, B.; Nusskern, D.; Rusch, D. B.; Salzberg, S.; Shao, W.; Shue, B.; Sun, J.; Wang, Z.; Wang, A.; Wang, X.; Wang, J.; Wei, M.; Wides, R.; Xiao, C.; Yan, C.; Yao, A.; Ye, J.; Zhan, M.; Zhang, W.; Zhang, H.; Zhao, Q.; Zheng, L.; Zhong, F.; Zhong, W.; Zhu, S.; Zhao, S.; Gilbert, D.; Baumhueter, S.; Spier, G.; Carter, C.; Cravchik, A.; Woodage, T.; Ali, F.; An, H.; Awe, A.; Baldwin, D.; Baden, H.; Barnstead, M.; Barrow, I.; Beeson, K.; Busam, D.; Carver, A.; Center, A.; Cheng, M. L.; Curry, L.; Danaher, S.; Davenport, L.; Desilets, R.; Dietz, S.; Dodson, K.; Doup, L.; Ferriera, S.; Garg, N.; Gluecksmann, A.; Hart, B.; Haynes, J.; Haynes, C.; Heiner, C.; Hladun, S.; Hostin, D.; Houck, J.; Howland, T.; Ibegwam, C.; Johnson, J.; Kalush, F.; Kline, L.; Koduru, S.; Love, A.; Mann, F.; May, D.; McCawley, S.; McIntosh, T.; McMullen, I.; Moy, M. Moy, L.; Murphy, B.; Nelson, K.; Pfannkoch, C.; Pratts, E.; Puri, V.; Qureshi, H.; Reardon, M.; Rodriguez, R.; Rogers, Y. H.; Romblad, D.; Ruhfel, B.; Scott, R.; Sitter, C.; Smallwood, M.; Stewart, E.; Strong, R.; Suh, E.; Thomas, R.; Tint, N. N.; Tse, S.; Vech, C.; Wang, G.; Wetter, J.; Williams, S.; Williams, M. Windsor, S.; Winn-Deen, E.; Wolfe, K. Zaveri, J.; Zaveri, K.; Abril, J. F.; Guigo, R.; Campbell, M. J.; Sjolander, K. V.; Karlak, B.; Kejariwal, A.; Mi, H.; Lazareva, B.; Hatton, T.; Narechania, A.; Diemer, K.; Muruganujan, A.; Guo, N.; Sato, S.; Bafna, V.; Istrail, S.; Lippert, R.; Schwartz, R.; Walenz, B.; Yooseph, S.; Allen, D. Basu, A: Baxendale, J: Blick, L. Caminha, M.: Carnes-Stine, J. Caulk, P.; Chiang, Y. H.; Coyne, M.; Dahlke, C.; Mays, A.; Dombroski, M.; Donnelly, M.; Ely, D.; Esparham, S.; Fosler, C.; Gire, H.; Glanowski, S.; Glasser, K.; Glodek, A.; Gorokhov, M.; Graham, K.; Gropman, B.; Harris, M.; Heil, J.; Henderson, S.; Hoover, J.; Jennings, D.; Jordan, C.; Jordan, J.; Kasha, J.; Kagan, L.; Kraft, C.; Levitsky, A.; Lewis, M.; Liu, X.; Lopez, J.; Ma, D.; Majoros, W.; McDaniel, J.; Murphy, S.; Newman, M.; Nguyen, T.; Nguyen, N.; Nodell, M.; Pan, S.; Peck, J.; Peterson, M.; Rowe, W.; Sanders, R.; Scott, J.; Simpson, M.; Smith, T.; Sprague, A.; Stockwell, T.; Turner, R.; Venter, E.; Wang, M.; Wen, M.; Wu, D.; Wu, M.; Xia, A.; Zandieh, A.; Zhu, X. The Sequence of the Human Genome. Science 2001, 291(5507), 1304-1351.

64. Consortium, I. H. G. S. Finishing the Euchromatic Sequence of the Human Genome. Nature 2004, 431(7011), 931-945.

65. Pheasant, M.; Mattick, J. S. Raising the Estimate of Functional Human Sequences. Genome Res. 2007, 17(9), 1245-1253.

66. Birney, E.; Stamatoyannopoulos, J. A.; Dutta, A.; Guigo, R.; Gingeras, T. R.; Margulies, E. H.; Weng, Z.; Snyder, M.; Dermitzakis, E. T.; Thurman, R. E.; Kuehn, M. S.; Taylor, C. M.; Neph, S.; Koch, C. M.; Asthana, S.; Malhotra, A.; Adzhubei, I.; Greenbaum, J. A.; Andrews, R. M.; Flicek, P.; Boyle, P. J.; Cao, H.; Carter, N. P.; Clelland, G. K.; Davis, S.; Day, N.; Dhami, P.; Dillon, S. C.; Dorschner, M. O.; Fiegler, H.; Giresi, P. G.; Goldy, J.; Hawrylycz, M.; Haydock, A.; Humbert, R.; James, K. D.; Johnson, B. E.; Johnson, E. M.; Frum, T. T.; Rosenzweig, E. R.; Karnani, N.; Lee, K.; Lefebvre, G. C.; Navas, P. A.; Neri, F.; Parker, S. C.; Sabo, P. J.; Sandstrom, R.; Shafer, A.; Vetrie, D.; Weaver, M.; Wilcox, S.; Yu, M.; Collins, F. S.; Dekker, J.; Lieb, J. D.; Tullius, T. D.; Crawford, G. E.; Sunyaev, S.; Noble, W. S.; Dunham, I.; Denoeud, F.; Reymond, A.; Kapranov, P.; Rozowsky, J.; Zheng, D.; Castelo, R.; Frankish, A.; Harrow, J.; Ghosh, S.; Sandelin, A.; Hofacker, I. L.;
Baertsch, R.; Keefe, D.; Dike, S.; Cheng, J.; Hirsch, H. A.; Sekinger, E. A.; Lagarde, J.; Abril, J. F.; Shahab, A.; Flamm, C.; Fried, C.; Hackermuller, J.; Hertel, J.; Lindemeyer, M.; Missal, K.; Tanzer, A.; Washietl, S.; Korbel, J.; Emanuelsson, O.; Pedersen, J. S.; Holroyd, N.; Taylor, R.; Swarbreck, D.; Matthews, N.; Dickson, M. C.; Thomas, D. J.; Weirauch, M. T.; Gilbert, J.; Drenkow, J.; Bell, I.; Zhao, X.; Srinivasan, K. G.; Sung, W. K.; Ooi, H. S.; Chiu, K. P.; Foissac, S.; Alioto, T.; Brent, M.; Pachter, L.; Tress, M. L.; Valencia, A.; Choo, S. W.; Choo, C. Y.; Ucla, C.; Manzano, C.; Wyss, C.; Cheung, E.; Clark, T. G.; Brown, J. B.; Ganesh, M.; Patel, S.; Tammana, H.; Chrast, J.; Henrichsen, C. N.; Kai, C.; Kawai, J.; Nagalakshmi, U.; Wu, J.; Lian, Z.; Lian, J.; Newburger, P.; Zhang, X.; Bickel, P.; Mattick, J. S.; Carninci, P.; Hayashizaki, Y. Weissman, S.; Hubbard, T.; Myers, R. M.; Rogers, J.; Stadler, P. F.; Lowe, T. M.; Wei, C. L.; Ruan, Y.; Struhl, K.; Gerstein, M.; Antonarakis, S. E.; Fu, Y.; Green, E. D.; Karaoz, U.; Siepel, A.; Taylor, J.; Liefer, L. A.; Wetterstrand, K. A.; Good, P. J.; Feingold, E. A.; Guyer, M. S.; Cooper, G. M. Asimenos, G.; Dewey, C. N.; Hou, M.; Nikolaev, S.; Montoya-Burgos, J. I. Loytynoja, A.; Whelan, S.; Pardi, F.; Massingham, T.; Huang, H.; Zhang, N. R.; Holmes, I.; Mullikin, J. C.; Ureta-Vidal, A.; Paten, B.; Seringhaus, M.; Church, D.; Rosenbloom, K.; Kent, W. J.; Stone, E. A.; Batzoglou, S.; Goldman, N.; Hardison, R. C.; Haussler, D.; Miller, W. Sidow, A.; Trinklein, N. D.; Zhang, Z. D.; Barrera, L.; Stuart, R.; King, D. C.; Ameur, A.; Enroth, S.; Bieda, M. C.; Kim, J.; Bhinge, A. A.; Jiang, N.; Liu, J.; Yao, F.; Vega, V. B.; Lee, C. W.; Ng, P.; Shahab, A.; Yang, A.; Moqtaderi, Z.; Zhu, Z.; Xu, X.; Squazzo, S.; Oberley, M. J.; Inman, D. Singer, M. A.; Richmond, T. A.; Munn, K. J.; Rada-Iglesias, A. Wallerman, O.; Komorowski, J.; Fowler, J. C.; Couttet, P.; Bruce, A. W.; Dovey, O. M.; Ellis, P. D.; Langford, C. F.; Nix, D. A.; Euskirchen, G.; Hartman, S.; Urban, A. E.; Kraus, P.; Van Calcar, S.; Heintzman, N.; Kim, T. H.; Wang, K.; Qu, C.; Hon, G.; Luna, R.; Glass, C. K.; Rosenfeld, M. G.; Aldred, S. F.; Cooper, S. J.; Halees, A.; Lin, J. M.; Shulha, H. P.; Zhang, X.; Xu, M.; Haidar, J. N.; Yu, Y.; Ruan, Y.; Iyer, V. R.; Green, R. D.; Wadelius, C.; Farnham, P. J.; Ren, B.; Harte, R. A.; Hinrichs, A. S.; Trumbower, H.; Clawson, H.; Hillman-Jackson, J.; Zweig, A. S.; Smith, K.; Thakkapallayil, A.; Barber, G.; Kuhn, R. M.; Karolchik, D. Armengol, L.; Bird, C. P.; de Bakker, P. I.; Kern, A. D.; Lopez-Bigas, N.; Martin, J. D.; Stranger, B. E.; Woodroffe, A.; Davydov, E.; Dimas, A.; Eyras, E.; Hallgrimsdottir, I. B.; Huppert, J.; Zody, M. C.; Abecasis, G. R.; Estivill, X.; Bouffard, G. G.; Guan, X.; Hansen, N. F.; Idol, J. R.; Maduro, V. V.; Maskeri, B.; McDowell, J. C.; Park, M.; Thomas, P. J. Young, A. C.; Blakesley, R. W.; Muzny, D. M.; Sodergren, E.; Wheeler, D. A.; Worley, K. C.; Jiang, H.; Weinstock, G. M.; Gibbs, R. A.; Graves, T.; Fulton, R.; Mardis, E. R.; Wilson, R. K.; Clamp, M.; Cuff, J.; Gnerre, S.; Jaffe, D. B.; Chang, J. L.; Lindblad-Toh, K.; Lander, E. S.; Koriabine, M.; Nefedov, M.; Osoegawa, K.; Yoshinaga, Y.; Zhu, B.; de Jong, P. J. Identification and Analysis of Functional Elements in 1\% of the Human Genome by the ENCODE Pilot Project. Nature 2007, 447(7146), 799816.

67. Orgel, L. E.; Crick, F. H. Selfish DNA: The Ultimate Parasite. Nature 1980, 284(5757), 604-607.

68. Doolittle, W. F.; Sapienza, C. Selfish Genes, the Phenotype Paradigm and Genome Evolution. Nature 1980, 284(5757), 601-603.

69. Volff, J. N. Turning Junk Into Gold: Domestication of Transposable Elements and the Creation of New Genes in Eukaryotes. BioEssays 2006, 28(9), 913-922.

70. Mattick, J. S.; Makunin, I. V. Noncoding RNA. Hum. Mol. Genet. 2006, 15 Spec No 1,R17-29.

71. Zuckerkandl, E.; Cavalli, G. Combinatorial Epigenetics, “Junk DNA," and the Evolution of Complex Organisms. Gene 2007, 390(1/2), 232242.

72. Claverie, J. M. Fewer Genes, More Noncoding RNA. Science 2005, 309(5740), 1529-1530.

73. Lee, R. C.; Feinbaum, R. L.; Ambros, V. The C. elegans Heterochronic Gene lin-4 Encodes Small RNAs with Antisense Complementarity to lin-14. Cell 1993, 75(5), 843-854.

74. Wightman, B.; Ha, I.; Ruvkun, G. Post-Transcriptional Regulation of the Heterochronic Gene lin-14 by lin-4 Mediates Temporal Pattern Formation in C. elegans. Cell 1993, 75(5), 855-862.

75. Bartel, D. P. MicroRNAs: Genomics, Biogenesis, Mechanism, and Function. Cell 2004, 116(2), 281-297.

76. Vasudevan, S.; Tong, Y.; Steitz, J. A. Switching from Repression to Activation: MicroRNAs Can Up-Regulate Translation. Science 2007, 318(5858), 1931-1934.

77. Winkler, W.; Nahvi, A.; Breaker, R. R. Thiamine Derivatives Bind Messenger RNAs Directly to Regulate Bacterial Gene Expression. Nature 2002, 419(6910), 952-956.

78. Nudler, E.; Mironov, A. S. The Riboswitch Control of Bacterial Metabolism. Trends Biochem. Sci. 2004, 29(1), 11-17.

79. Nahvi, A.; Sudarsan, N.; Ebert, M. S.; Zou, X.; Brown, K. L.; Breaker R. R. Genetic Control by a Metabolite Binding mRNA. Chem. Biol. 2002, 9(9), 1043-1049.

80. Edwards, T. E.; Klein, D. J.; Ferre-D'Amare, A. R. Riboswitches: Small-Molecule Recognition by Gene Regulatory RNAs. Curr. Opin. Struct. Biol. 2007, 17(3), 273-279.

81. Hossain, M.; Limbach, P.A. Mass Spectrometry-Based Detection of Transfer RNAs by Their Signature Endonuclease Digestion Products. RNA 2007, 13(2), 295-303.

82. Hossain, M.; Limbach, P.A. Multiple Endonucleases Improve MALDI-MS Signature Digestion Product Detection of Bacterial Transfer RNAs. Anal. Bioanal. Chem. 2009, 394(4), 1125-1135. 
83. Meng, Z.; Limbach, P.A. Quantitation of Ribonucleic Acids Using $18 \mathrm{O}$ Labeling and Mass Spectrometry. Anal. Chem. 2005, 77(6), 1891-1895.

84. Huttenhofer, A.; Vogel, J. Experimental Approaches to Identify Noncoding RNAs. Nucleic Acids Res. 2006, 34(2), 635-646.

85. Marioni, J. C.; Mason, C. E.; Mane, S. M.; Stephens, M.; Gilad, Y. RNA-seq: An Assessment of Technical Reproducibility and Comparison with Gene Expression Arrays. Genome Res. 2008, 18(9), 1509-1517.

86. Neubauer, G.; Gottschalk, A.; Fabrizio, P.; Seraphin, B.; Luhrmann, R.; Mann, M. Identification of the Proteins of the Yeast U1 Small Nuclear Ribonucleoprotein Complex by Mass Spectrometry. Proc. Natl. Acad. Sci. U.S.A. 1997, 94(2), 385-390.

87. Kumar, R.; Reynolds, D. M.; Shevchenko, A.; Shevchenko, A.; Goldstone, S. D.; Dalton, S. Forkhead Transcription Factors, Fkh1p and Fkh2p, Collaborate with Mcm1p to Control Transcription Required for M-Phase. Curr. Biol. 2000, 10(15), 896-906.

88. Rusconi, F.; Guillonneau, F.; Praseuth, D. Contributions of Mass Spectrometry in the Study of Nucleic Acid-Binding Proteins and of Nucleic Acid-Protein Interactions. Mass Spectrom. Rev. 2002, 21, 305348.

89. Steen, H.; Jensen, O. N. Analysis of Protein-Nucleic Acid Interactions by Photochemical Cross-Linking and Mass Spectrometry. Mass Spectrom. Rev. 2002, 21(3), 163-182.

90. Forde, C. E.; McCutchen-Maloney, S. L. Characterization of Transcription Factors by Mass Spectrometry and the Role of SELDI-MS. Mass Spectrom. Rev. 2002, 21(6), 419-439.

91. Smith, C. A.; O'Maille, G.; Want, E. J.; Qin, C.; Trauger, S. A.; Brandon, T. R.; Custodio, D. E.; Abagyan, R.; Siuzdak, G. METLIN: A Metabolite Mass Spectral Database. Ther. Drug Monit. 2005, 27(6), 747-751.

92. Kopka, J.; Schauer, N.; Krueger, S.; Birkemeyer, C.; Usadel, B.; Bergmuller, E.; Dormann, P.; Weckwerth, W.; Gibon, Y.; Stitt, M.; Willmitzer, L.; Fernie, A. R.; Steinhauser, D. GMD@CSB.DB: The Golm Metabolome Database. Bioinformatics 2005, 21(8), 1635-1638.

93. Markley, J. L.; Anderson, M. E.; Cui, Q.; Eghbalnia, H. R.; Lewis, I. A.; Hegeman, A. D.; Li, J.; Schulte, C. F.; Sussman, M. R.; Westler, W. M.; Ulrich, E. L.; Zolnai, Z. New Bioinformatics Resources for Metabolomics. Pac. Symp. Biocomput 2007, 12, 157-168.

94. Wishart, D. S.; Tzur, D.; Knox, C.; Eisner, R.; Guo, A. C.; Young, N.; Cheng, D.; Jewell, K.; Arndt, D.; Sawhney, S.; Fung, C.; Nikolai, L.; Lewis, M.; Coutouly, M. A.; Forsythe, I.; Tang, P.; Shrivastava, S.; Jeroncic, K.; Stothard, P.; Amegbey, G.; Block, D.; Hau, D. D.; Wagner, J.; Miniaci, J.; Clements, M.; Gebremedhin, M.; Guo, N.; Zhang, Y.; Duggan, G. E.; Macinnis, G. D.; Weljie, A. M.; Dowlatabadi, R.; Bamforth, F.; Clive, D.; Greiner, R.; Li, L.; Marrie, T.; Sykes, B. D.; Vogel, H. J.; Querengesser, L. HMDB: The Human Metabolome Database. Nucleic Acids Res 2007, 35, D521-526.

95. Ganem, B.; Li, Y.-T.; Henion, J. D. Detection of Oligonucleotide Duplex Forms by Ion-Spray Mass Spectrometry. Tetrahedron Lett. 1993, 34, 1445-1448.

96. Light-Wahl, K. J.; Springer, D. L.; Winger, B. E.; Edmonds, C. G.; II, Thrall, B. D.; Smith, R. D. Observation of a Small Oligonucleotide Duplex by Electrospray Ionization Mass Spectrometry. J. Am. Chem. Soc. 1993, 115, 803-804.

97. Doktycz, M. J.; Habibi-Goudarzi, S.; McLuckey, S.A. Accumulation and Storage of Ionized Duplex DNA Molecules in a Quadrupole Ion Trap. Anal. Chem. 1994, 66(20), 3416-3422.

98. Lecchi, P.; Le, H. M.; Pannell, L. K. 6-Aza-2-Thiothymine: A Matrix for MALDI Spectra of Oligonucleotides. Nucleic Acids Res. 1995, 23(7), $1276-1277$.

99. Lecchi, P.; Pannell, L. K. The Detection of Intact Double-Stranded DNA by MALDI. Am. Soc. Mass Spectrom. 1995, 6, 972-975.

100. Kirpekar, F.; Berkenkamp, S.; Hillenkamp, F. Detection of DoubleStranded DNA by IR- and UV-MALDI Mass Spectrometry. Anal. Chem. 1999, 71(13), 2334-2339.

101. Distler, A. M.; Allison, J. Additives for the Stabilization of DoubleStranded DNA in UV-MALDI MS. J. Am. Soc. Mass Spectrom. 2002, 13(9), 1129-1137.

102. Loo, J. A. Studying Noncovalent Protein Complexes by Electrospray Ionization Mass Spectrometry. Mass Spectrom. Rev. 1997, 16, 1-23.

103. Beck, J. L.; Colgrave, M. L.; Ralph, S. F.; Sheil, M. M. Electrospray Ionization Mass Spectrometry of Oligonucleotide Complexes with Drugs, Metals, and Proteins. Mass Spectrom. Rev. 2001, 20, 61-87.

104. Hofstadler, S. A.; Griffey, R. H. Analysis of Noncovalent Complexes of DNA and RNA by Mass Spectrometry. Chem. Rev. 2001, 101(2), 377-390.

105. Hanson, C. L.; Robinson, C.V. Protein-Nucleic Acid Interactions and the Expanding Role of Mass Spectrometry. J. Biol. Chem. 2004, 279(24), 24907-24910.

106. Goodlett, D. R.; Camp, D. G. II; Hardin, C. C.; Corregan, M.; Smith, R. D. Direct Observation of a DNA Quadruplex by Electrospray Ionization Mass Spectrometry. Rapid Commun. Mass Spectrom. 1993, 22, 181-183.

107. Bayer, E.; Bauer, T.; Schmeer, K.; Bleicher, K.; Maier, M.; Gaus, H. J. Analysis of Double-Stranded Oligonucleotides by Electrospray Mass Spectrometry. Anal. Chem. 1994, 66(22), 3858-3863.

108. Wunschel, D. S.; Fox, K. F.; Fox, A.; Bruce, J. E.; Muddiman, D. C. Smith, R. D. Analysis of Double-Stranded Polymerase Chain Reaction Products from the Bacillus cereus Group by Electrospray Ionization Fourier Transform Ion Cyclotron Resonance Mass Spectrometry. Rapid Commun. Mass Spectrom. 1996, 10(1), 29-35.
109. Rodrigues Hoyne, P.; Benson, L. M.; Veenstra, T. D.; Maher, L. J. III; Naylor, S. RNA-RNA Noncovalent Interactions Investigated by Microspray Ionization Mass Spectrometry. Rapid Commun. Mass Spectrom. 2001, 15(17), 1539-1547.

110. David, W. M.; Brodbelt, J. S.; Kerwin, S. M.; Thomas, P. W. Investigation of Quadruplex Oligonucleotide-Drug interaction by Electrospray Ionization Mass Spectrometry. Anal. Chem. 2002, 74, 2029-2033.

111. Cheng, X.; Harms, A. C.; Goudreau, P. N.; Terwilliger, T. C.; Smith, R. D. Direct Measurement of Oligonucleotide Binding Stoichiometry of Gene V Protein by Mass Spectrometry. Proc. Natl. Acad. Sci. U.S.A. 1996, 93(14), 7022-7027.

112. Cheng, X.; Morin, P. E.; Harms, A. C.; Bruce, J. E.; Ben-David, Y.; Smith, R. D. Mass Spectrometric Characterization of Sequence-Specific Complexes of DNA and Transcription Factor PU 1 DNA Binding Domain. Anal. Biochem. 1996, 239, 35-40.

113. Sannes-Lowery, K. A.; Hu, P.; Mack, D. P.; Mei, H. Y.; Loo, J. A. HIV-1 Tat Peptide Binding to TAR RNA by Electrospray Ionization Mass Spectrometry. Anal. Chem. 1997, 69(24), 5130-5135.

114. Potier, N.; Donald, L. J.; Chernushevich, I.; Ayed, A.; Ens, W.; Arrowsmith, C. H.; Standing, K.; Duckworth, H. W. Study of a Noncovalent TRP Repressor-DNA Operator Complex by Electrospray Ionization Time-of-Flight Mass Spectrometry. Protein Sci. 1998, 7(6), 1388-1395.

115. Craig, T. A.; Benson, L. M.; Tomlinson, A. J.; Veenstra, T. D.; Naylor, S.; Kumar, R. Analysis of Transcription Complexes and Effects of Ligands by Microspray Ionization Mass Spectrometry. Nat. Biotechnol. 1999, 17(12), 1214-1218.

116. Deterding, L. J.; Kast, J.; Przybylski, M.; Tomer, K. B. Molecular Characterization of a Tetramolecular Complex Between dsDNA and a DNA-Binding Leucine Zipper Peptide Dimer by Mass Spectrometry. Bioconj. Chem. 2000, 11(3), 335-344.

117. Hsieh, Y. L.; Li, Y. T.; Henion, J. D.; Ganem, B. Studies of Noncovalent Interactions of Actinomycin D with Single-Stranded Oligodeoxynucleotides by Ion Spray Mass Spectrometry and Tandem Mass Spectrometry. Biol. Mass Spectrom. 1994, 23(5), 272-276.

118. Gale, D. C.; Goodlett, D .R.; Light-Wahl, K. J.; Smith, R. D. Observation of Duplex DNA-Drug Noncovalent Complexes by Electrospray Mass Spectrometry. J. Am. Chem. Soc. 1994, 116, 6027-6028.

119. Triolo, A.; Arcamone, F. M.; Raffaelli, A.; Salvadori, P. Noncovalent Complexes Between DNA-Binding Drugs and Double-Stranded Deoxynucleotides: A Study by Ion Spray Mass Spectrometry. J. Mass Spectrom. 1997, 32, 1186-1194.

120. Gupta, R.; Kapur, A.; Beck, J. L.; Sheil, M. M. Positive Ion Electrospray Ionization Mass Spectrometry of Double-Stranded DNA/Drug Complexes. Rapid Commun. Mass Spectrom. 2001, 15(24), 2472-2480.

121. Greig, M.; Gaus, H.; Cummins, L. L.; Sasmor, H.; Griffey, R. H. Measurement of Macromolecular Binding Using Electrospray Mass Spectrometry. Determination of Dissociation Constants for Oligonucleotide-Serum Albumin Complexes. J. Am. Chem. Soc. 1995, 117, 10765-10766.

122. Kapur, A.; Beck, J. L.; Brown, S. E.; Dixon, N. E.; Sheil, M. M. Use of Electrospray Mass Spectrometry to Study the Binding Interactions Between a Replication Terminator Protein and DNA. Protein Sci. 2002, 11(1), 147-157.

123. Griffey, R. H.; Hofstadler, S. A.; Sannes-Lowery, K. A.; Ecker, D. J.; Crooke, S. T. Determinants of Aminoglycoside-Binding Specificity for rRNA by Using Mass Spectrometry. Proc. Nat. Acad. Sci. U.S.A. 1999, 96(18), 10129-10133.

124. Wan, K. X.; Shibue, T.; Gross, M. L. Noncovalent Complexes Between DNA-Binding Drugs and Double-Stranded Oligodeoxynucleotides: A Study by ESI Ion-Trap Mass Spectrometry. J. Am. Chem. Soc. 2000, 122, 300-307.

125. Sannes-Lowery, K. A.; Griffey, R. H.; Hofstadler, S. A. Measuring Dissociation Constants of RNA and Aminoglycoside Antibiotics by Electrospray Ionization Mass Spectrometry. Anal. Biochem. 2000, 280(2), 264-271.

126. Rosu, F.; Gabelica, V.; Houssier, C.; De Pauw, E. Determination of Affinity, Stoichiometry, and Sequence Selectivity of Minor Groove Binder Complexes with Double-Stranded Oligodeoxynucleotides by Electrospray Ionization Mass Spectrometry. Nucleic Acids Res. 2002, 30(16), e82.

127. Hagan, N.; Fabris, D. Direct Mass Spectrometric Determination of the Stoichiometry and Binding Affinity of the Complexes Between HIV-1 Nucleocapsid Protein and RNA Stem-Loops Hairpins of the HIV-1

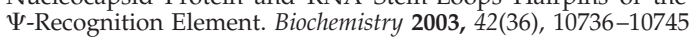

128. Gooding, K. B.; Higgs, R.; Hodge, B.; Stauffer, E.; Heinz, B.; McKnight, K.; Phipps, K.; Shapiro, M.; Winkler, M.; Ng, W. L.; Julian, R. K. High Throughput Screening of Library Compounds Against an Oligonucleotide Substructure of an RNA Target. J. Am. Soc. Mass Spectrom. 2004, 15(6), 884-892.

129. Daniel, J. M.; Friess, S. D.; Rajagopalan, S.; Wendt, S.; Zenobi, R. Quantitative Determination of Noncovalent Binding Interactions Using Soft Ionization Mass Spectrometry. Int. J. Mass Spectrom. Ion Processes 2002, 216, 1-27.

130. Mei, H. Y.; Mack, D.; Galan, A. A.; Halim, N. S.; Heldsinger, A.; Loo, J. A.; Moreland, D. W.; Sannes-Lowery, K. A.; Sharmeen, L.; Truong, H. N.; Czarnik, A. W. Discovery of Selective, Small-Molecule Inhibitors of RNA Complexes. I. The Tat Protein/TAR RNA Complexes Required for HIV-1 Transcription. Bioorg. Med. Chem. 1997, 5(6), 11731184 .

131. Gabelica, V.; De Pauw, E.; Rosu, F. Interaction Between Antitumor Drugs and a Double-Stranded Oligonucleotide Studied by Electros- 
pray Ionization Mass Spectrometry. J. Mass Spectrom. 1999, 34(12), $1328-1337$.

132. Sannes-Lowery, K. A.; Mei, H.-Y.; Loo, J. A. Studying Aminoglycoside Antibiotic Binding to HIV-1 TAR RNA by Electrospray Ionization Mass Spectrometry. Int. J. Mass Spectrom. Ion Processes 1999, 193, $115-122$.

133. Hofstadler, S. A.; Sannes-Lowery, K. A.; Crooke, S. T.; Ecker, D. J.; Sasmor, H.; Manalili, S.; Griffey, R. H. Multiplexed Screening of Neutral Mass-Tagged RNA Targets Against Ligand Libraries with Electrospray Ionization FTICR MS: A Paradigm for High-Throughput Affinity Screening. Anal. Chem. 1999, 7(16), 3436-3440.

134. Turner, K. B.; Brinson, R. G.; Yi-Brunozzi, H. Y.; Rausch, J. W.; Miller, J. T.; Le Grice, S. F. J.; Marino, J. P.; Fabris, D. Structural Probing of HIV-1 Polypurine Tract RNA:DNA Hybrid Using Classic Nucleic Acid Ligands. Nucleic Acids Res. 2008, 36, 2799-2810.

135. Turner, K. B.; Hagan, N. A.; Fabris, D. Inhibitory Effects of Archetypical Nucleic Acid Ligands on the Interactions of HIV-1 Nucleocapsid Protein with Elements of $\Psi$-RNA. Nucl. Acids Res. 2006, 34(5), 1305-1316.

136. Gale, D. C.; Smith, R. D. Characterization of Noncovalent Complexes Formed Between Minor Groove Binding Molecules and Duplex DNA by Electrospray Ionization-Mass Spectrometry. J. Am. Soc. Mass Spectrom. 1995, 6, 1154-1164.

137. Kapur, A.; Beck, J. L.; Sheil, M. M. Observation of Daunomycin and Nogalamycin Complexes with Duplex DNA Using Electrospray Ionization Mass Spectrometry. Rapid Commun. Mass Spectrom. 1999, 13, 2489-2497.

138. Rostom, A. A.; Fucini, P.; Benjamin, D. R.; Juenemann, R.; Nierhaus, K. H.; Hartl, F. U.; Dobson, C. M.; Robinson, C. V. Detection and Selective Dissociation of Intact Ribosomes in a Mass Spectrometer. Proc. Nat. Acad. Sci. U.S.A. 2000, 97(10), 5185-5190.

139. Liu, C. Pasa-Tolic, L. Hofstadler, S. A. Harms, A. C. Smith, R. D. Kang, C.; Sinha, N. Probing RegA/RNA Interactions Using Electrospray Ionization-Fourier Transform Ion Cyclotron Resonance-Mass Spectrometry. Anal. Biochem. 1998, 262(1), 67-76.

140. Reyzer, M. L.; Brodbelt, J. S.; Kerwin, S. M.; Kumar, D. Evaluation of Complexation of Metal-Mediated DNA-Binding Drugs to Oligonucleotides Via Electrospray Ionization Mass Spectrometry. Nucleic Acids Res. 2001, 29(21), e103.

141. Rosu, F.; Gabelica, V.; Houssier, C.; Colson, P.; De Pauw, E. Triplex and Quadruplex DNA Structures Studied by Electrospray Mass Spectrometry. Rapid Commun. Mass Spectrom. 2002, 16(18), 1729-1736.

142. Wan, K. X.; Gross, M. L; Shibue, T. Gas-Phase Stability of DoubleStranded Oligodeoxynucleotides and Their Noncovalent Complexes with DNA-Binding Drugs as Revealed by Collisional Activation in an Ion Trap. J. Am. Soc. Mass Spectrom. 2000, 11(5), 450-457.

143. Gabelica, V.; Rosu, F. Houssier, C.; De Pauw, E. Gas Phase Thermal Denaturation of an Oligonucleotide Duplex and Its Complexes with Minor Groove Binders. Rapid Commun. Mass Spectrom. 2000, 14(6), 464-467.

144. Gabelica, V.; De Pauw, E. Comparison of the Collision-Induced Dissociation of Duplex DNA at Different Collision Regimes: Evidence for a Multistep Dissociation Mechanism. J. Am. Soc. Mass Spectrom. 2002, 13(1), 91-98

145. Gabelica, V.; De Pauw, E. Comparison Between Solution-Phase Stability and Gas-Phase Kinetic Stability of Oligodeoxynucleotide Duplexes. J. Mass Spectrom. 2001, 36(4), 397-402.

146. Schnier, P. D.; Klassen, J. S.; Strittmatter, E. F.; Williams, E. R. Activation Energies for Dissociation of Double Strand Oligonucleotide Anions: Evidence for Watson-Crick Base Pairing in Vacuo. J. Am. Chem. Soc. 1998, 120(37), 9605-9613.

147. Mazzitelli, C. L. Brodbelt, J. S. Kern, J. T. Rodriguez, M. Kerwin, S. M. Evaluation of Binding of Perylene Diimide and Benzannulated Perylene Diimide Ligands to DNA by Electrospray Mass Spectrometry. J. Am. Soc. Mass Spectrom. 2006, 17, 593-604.

148. Yu, E.; Fabris, D. Direct Probing of RNA Structures and RNA-Protein Interactions in the HIV-1 Packaging Signal by Chemical Modification and Electrospray Ionization Fourier Transform Mass Spectrometry. J. Mol. Biol. 2003, 330(2), 211-223.

149. Yu, E. T.; Fabris, D. Toward Multiplexing the Application of Solvent Accessibility Probes for the Investigation of RNA Three-Dimensional Atructures by Electrospray Ionization-Fourier Transform Mass Spectrometry. Anal. Biochem. 2004, 344, 356-366.

150. Kellersberger, K. A.; Yu, E.; Kruppa, G. H.; Young, M. M.; Fabris, D. Top-Down Characterization of Nucleic Acids Modified by Structural Probes Using High-Resolution Tandem Mass Spectrometry and Automated Data Interpretation.Anal. Chem. 2004, 76(9), 2438-2445.

151. Zhang, Q.; Yu, E. T.; Kellersberger, K. A.; Crosland, E.; Fabris, D. Toward Building a Database of Bifunctional Probes for the MS3D Investigation of Nucleic Acids Structures.J. Am. Soc. Mass Spectrom. 2006, 17, 1570-1581.

152. Yu, E. T.; Zhang, Q.; Fabris, D. Untying the FIV Frameshifting Pseudoknot Structure by MS3D. J. Mol. Biol. 2005, 345, 69-80.

153. Yu, E. T.; Hawkins, A. E.; Eaton, J.; Fabris, D. MS3D Structural Elucidation of the HIV-1 Packaging Signal. Proc. Natl. Acad .Sci. U.S.A. 2008, 105, 12248-12253.

154. Jensen, O. N.; Barofsky, D. F.; Young, M. C.; von Hippel, P. H.; Swenson, S.; Seifried, S. E. Direct Observation of UV-Crosslinked Protein-Nucleic Acid Complexes by Matrix-Assisted Laser Desorption Ionization Mass Spectrometry. Rapid Commun. Mass Spectrom. 1993, 7(6), 496-501.
155. Jensen, O. N.; Kulkarni, S.; Aldrich, J. V.; Barofsky, D .F. Characterization of Peptide-Oligonucleotide Heteroconjugates by Mass Spectrometry. Nucleic Acids Res. 1996, 24(19), 3866-3872.

156. Golden, M. C.; Resing, K. A.; Collins, B .D.; Willis, M. C.; Koch, T. H. Mass Spectral Characterization of a Protein-Nucleic Acid Photocrosslink. Protein Sci. 1999, 8(12), 2806-2812.

157. Geyer, H.; Geyer, R.; Pingoud, V. A Novel Strategy for the Identification of Protein-DNA Contacts by Photocrosslinking and Mass Spectrometry. Nucl. Acids Res. 2004, 32, e132.

158. Thiede, B.; Urlaub, H.; Neubauer, H.; Grelle, G.; Wittmann-Liebold, B Precise Determination of RNA-Protein Contact Sites in the $50 \mathrm{~S}$ Ribosomal Subunit of Escherichia coli. Biochem J. 1998, 334(Pt. 1), 39-42.

159. Urlaub, H.; Raker, V. A.; Kostka, S.; Luhrmann, R. Sm Protein-Sm Site RNA Interactions Within the Inner Ring of the Spliceosomal snRNP Core Structure. EMBO I 2001, 20(1/2), 187-196.

160. Will, C. L.; Urlaub, H.; Achsel, T.; Gentzel, M.; Wilm, M.; Luhrmann, R. Characterization of Novel SF3b and 17S U2 snRNP Proteins, Including a Human Prp5p Homologue and an SF3b DEAD-Box Protein. EMBO J. 2002, 21(18), 4978-4988

161. Johnston, P. D.; Redfield, A.G. An NMR Study of the Exchange Rates for Protons Involved in the Secondary and Tertiary Structure of Yeast tRNA Phe. Nucleic Acids Res. 1977, 4(10), 3599-3615.

162. Englander, S. W.; Sosnick, T. R.; Englander, J. J.; Mayne, L. Mechanisms and Uses of Hydrogen Exchange. Curr. Opin. Struct. Biol. 1996, $6(1), 18-23$.

163. Ma, L.; Fitzgerald, M. C. A New H/D Exchange- and Mass Spectrometry-Based Method for Thermodynamic Analysis of Protein-DNA Interactions. Chem Biol. 2003, 10(12), 1205-1213.

164. Sperry, J. B.; Shi, X.; Rempel, D. L.; Nishimura, Y.; Akashi, S.; Gross, M. L. A Mass Spectrometric Approach to the Study of DNA-Binding Proteins: Interaction of Human TRF2 with Telomeric DNA. Biochemistry 2008, 47(6), 1797-1807.

165. Sperry, J. B.; Wilcox, J. M.; Gross, M. L. Strong Anion Exchange for Studying Protein-DNA Interactions by H/D Exchange Mass Spectrometry. J. Am. Soc. Mass Spectrom. 2008, 19(6), 887-890.

166. Freitas, M. A.; Marshall, A. G. Gas Phase RNA and DNA Ions. 2. Conformational Dependence of the Gas-Phase H/D Exchange of Nucleotide-5'-Monophosphates. J. Am. Soc. Mass Spectrom. 2001, 12(7), $780-785$

167. Balbeur, D.; Dehareng, D; De Pauw, E. Conformationally Driven Gas-Phase H/D Exchange of Dinucleotide Negative Ions. J. Am. Soc. Mass Spectrom. 2007, 18(10), 1827-1834.

168. Hofstadler, S. A.; Sannes-Lowery, K. A.; Griffey, R. H. Enhanced Gas-Phase Hydrogen-Deuterium Exchange of Oligonucleotide and Protein Ions Stored in an External Multipole Ion Reservoir. J. Mass Spectrom. 2000, 35(1), 62-70.

169. Balbeur, D.; Widart, J.; Leyh, B.; Cravello, L.; De Pauw, E. Detection of Oligonucleotide Gas-Phase Conformers: H/D Exchange and Ion Mobility as Complementary Techniques. J. Am. Soc. Mass Spectrom. 2008, 19(7), 938-946.

170. Mo, J.; Todd, G. C.; Hakansson, K. Characterization of Nucleic Acid Higher Order Structure by Gas-Phase H/D Exchange in a QuadrupoleFT-ICR Mass Spectrometer. Biopolymers 2009, 91(4), 256-264.

171. Turner, K. B.; Hagan, N.A.; Kohlway, A.; Fabris, D. Mapping Noncovalent Ligand Binding to Stemloop Domains of the HIV-1 Packaging Signal by Tandem Mass Spectrometry J. Am. Soc. Mass Spectrom. 2006, 17, 1401-1411.

172. Turner, K. B.; Kohlway, A. S.; Hagan, N. A.; Fabris, D. Noncovalent Probes for the Investigation of Structure and Dynamics of ProteinNucleic Acid Assemblies: The Case of NC-Mediated Dimerization of Genomic RNA in HIV-1. Biopolymers 2009, 91(4), 283-296.

173. Griffey, R. H.; Greig, M. J.; Haoyun, A.; Sasmor, H.; Manalili, S. Targeted Site-Specific Gas-Phase Cleavage of Oligoribonucleotides. Application in Mass Spectrometry-Based Identification of Ligand Binding Sites. J. Am. Chem. Soc. 1999, 121, 474-475.

174. Hanson, C. L.; Fucini, P.; Ilag, L. L.; Nierhaus, K. H.; Robinson, C. V. Dissociation of Intact Escherichia coli Ribosomes in a Mass Spectrometer-Evidence for Conformational Change in a Ribosome Elongation Factor G Complex. J. Biol. Chem. 2002, 278(2), 1259-1267.

175. Turner, K. B.; Hagan, N. A.; Fabris, D. Understanding the Isomerization of the HIV-1 Dimerization Initiation Domain by the Nucleocapsid Protein. J. Mol. Biol. 2007, 369, 812-828.

176. Baker, E. S.; Dupuis, N. F.; Bowers, MT. DNA Hairpin, Pseudoknot and Cruciform Stability in a Solvent-Free Environment. J. Phys. Chem. B 2009, 113(6), 1722-1727.

177. Stults, J. T.; Marsters, J. C.; Carr, S. A. Improved Electrospray Ionization of Synthetic Oligodeoxynucleotides. Rapid Commun. Mass Spectrom. 1991, 5 , 359-363.

178. Nordhoff, E.; Ingendoh, A.; Cramer, R.; Overberg, A.; Stahl, B.; Karas, M.; Hillenkamp, F.; Crain, P. F. Matrix-Assisted Laser Desorption/ Ionization Mass Spectrometry of Nucleic Acids with Wavelengths in the Ultraviolet and Infrared. Rapid Commun. Mass Spectrom. 1992, 6(12), 771-776.

179. Little, D. P.; Thannhauser, T. W.; McLafferty, F. W. Verification of 50to 100-mer DNA and RNA Sequences with High-Resolution Mass Spectrometry. Proc. Natl. Acad. Sci. U.S.A. 1995, 92(6), 2318-2322.

180. Limbach, P. A.; Crain, P. F.; McCloskey, J. A. Molecular Mass Measurement of Intact Ribonucleic Acids Via Electrospray Ionization Quadrupole Mass Spectrometry. J. Am. Soc. Mass Spectrom. 1995, 6, 27-39. 
181. Muddiman, D. C.; Cheng, X.; Udseth, H. R.; Smith, R. D. Charge-State Reduction with Improved Signal Intensity of Oligonucleotides in Electrospray Ionization Mass Spectrometry. J. Am. Soc. Mass Spectrom. 1996, 7, 697-706.

182. Liu, C.; Wu, Q.; Harms, A. C.; Smith, R. D. On-Line Microdialysis Sample Cleanup for Electrospray Ionization Mass Spectrometry of Nucleic Acid Samples. Anal. Chem. 1996, 68(18), 3295-3299.

183. Xu, N.; Y.; Lin, Y.; Hofstadler, S. A.; Matson, D.; Call, C. J.; Smith, R. D. A Microfabricated Dialysis Device for Sample Cleanup in Electrospray Ionization Mass Spectrometry. Anal. Chem. 1998, 70(17), 3553-3556.

184. Hannis, J. C.; Muddiman, D. C. Characterization of a Microdialysis Approach to Prepare Polymerase Chain Reaction Products for Electrospray Ionization Mass Spectrometry Using On-Line Ultraviolet Absorbance Measurements and Inductively Coupled Plasma Atomic Emission Spectroscopy. Rapid Commun. Mass Spectrom. 1999, 13, 323-330.
185. Turner, K. B.; Monti, S.; Fabris, D. Like Polarity Ion-Ion Reactions Enable the Investigation of Specific Metal Interactions in Nucleic Acids and Their Noncovalent Assemblies. J. Am. Chem. Soc. 2008, 30, 1335313363.

186. Zubarev, R. A.; Kelleher, N. L.; McLafferty, F. W. Electron Capture Dissociation of Multiply Charged Protein Cations: A Nonergodic Process. J. Am. Chem. Soc. 1998, 120, 3265-3266.

187. Syka, J. E. P.; Coon, J. J.; Schroeder, M. J.; Shabanowitz, J.; Hunt, D. F. Peptide and Protein Sequence Analysis by Electron Transfer Dissociation Mass Spectrometry. Proc. Nat. Acad. Sci. U.S.A. 2004, 101, 9528-9533.

188. Yang, J.; Mo, J.; Adamson, J. T.; Hakansson, K. Characterization of Oligodeoxynucleotides by Electron Detachment Dissociation Fourier Transform Ion Cyclotron Resonance Mass Spectrometry. Anal. Chem. 2005, 77(6), 1876-1882. 